\title{
The Street Walkability and Thermal Comfort Index (SWTCI): A new assessment tool combining street design measurements and thermal comfort
}

\author{
Kahina Labdaoui $^{* a, b}$, Said Mazouz ${ }^{\mathrm{d}}$, Mehdi Moeinaddinic ${ }^{\mathrm{c}}$, Mario Cools ${ }^{\text {,b, e, f }}$, Jacques Teller ${ }^{\mathrm{b}}$ \\ DOI: 10.1016/j.scitotenv.2021.148663
}

Abstract

In recent years, walkability is increasingly integrated into sustainability strategies, considering its many health and environmental benefits. Besides, thermal comfort also has been progressively promoted as a critical measure for pedestrian comfort and wellbeing. Despite the relevance of the two concepts, few studies combined them in a comprehensive model. This study considers thermal comfort in assessing walkability by developing a new measurement tool, the Street Walkability and Thermal Comfort index (SWTCI), which focuses on comfort facilities and Physiological Equivalent Temperature (PET), at the street scale. The applied point system method requires combining a questionnaire survey, observations, and in situ measurements (air temperature, wind velocity, and relative humidity). The questionnaire survey (330 responders) measured 21 street design indicators' importance, using a five-point Liker scale ranging from 1 (least important) to 5 (very important). The observation technique seeks to evaluate every pedestrian comfort indicator score $\left(\mathrm{Si}_{\mathrm{s}}\right)$. The in situ measurements permit Envi-met's calibrated data validation and getting the mean radian temperature $\left(\mathrm{T}_{\mathrm{mrt}}\right)$. Those were considered in the PET's calculation using Rayman software. Three distinct streets have been chosen in Annaba city, Algeria, within the Mediterranean climate (Csa). The results show that the SWTCI achieves its highest score on the three streets when the thermal perception is neutral $(20<$ PET $<26)$, and its lowest score, with a warm thermal sensation $(28<$ PET $<31)$. Despite the divergence in PET values, the highest score of SWTCI was 33\%, reflecting a low comfort quality and minimal pedestrian facilities. Applying the SWTCI method can transform uncomfortable streets into an ideal walkable and pleasant path by finding the problems and proposing improvements.

Keywords: Mediterranean climate (Csa), Street level, Street Walkability Thermal Comfort index (SWTCI), Thermal comfort, the Physiological Equivalent Temperature (PET), Walkability. 


\section{Introduction}

Walking is considered the primary transport mode for people (Asadi-Shekari et al., 2019). It is also crucial in promoting a healthier and sustainable environment by reducing traffic congestion, obesity rate and improving liveability (Moura et al., 2017).The urban environment components (e.g., streets, parks, squares) have a critical role in enhancing the waking experience (Ruiz-Padillo et al., 2018).Various studies focused on evaluating walkability at the street level (Aghaabbasi et al., 2019, 2017; Asadi-Shekari et al., 2015) since it is the main pedestrian activity space. The street design and facilities can encourage and discourage walking. For example, urban design features such as shade trees and benches offer a pleasant walking experience (Battista and Manaugh, 2018). Drinking fountains, lighting, benches and seating area, and landscape and trees (Asadi-Shekari et al., 2013a, 2014) provide usability, safety, and attractiveness for pedestrians (Aghaabbasi et al., 2019).

According to Asadi-Shekari et al.(2019), walking rates depend on pedestrian facilities (Rodríguez et al., 2008). Designing a comfortable pedestrian environment could be achieved by operational assessment tools that involved sustained measurement and analysis of the sidewalk facilities and thermal comfort. Many studies explored walkability assessment tools at the street scale. The Level of Service(LOS) is a measurement tool for evaluating the quality of service, street facilities, and infrastructure (Asadi-Shekari et al., 2014, 2019; Moeinaddini et al., 2013). Sarkar (1993) proposed a (LOS) for the pedestrian. Based on factors that affect safety, security, comfort, system coherence, and attractiveness (Nilles and Kaparias, 2018). However, the LOS models have not included many comfort facilities besides pedestrian's characteristics such as age categories and abilities.

The pedestrian level of service (PLOS) is an essential tool for promoting existing infrastructure, managing new investments, and guiding appropriate contributions 
(Christopoulou and Pitsiava-Latinopoulou, 2012). By identifying the deficiency in the pedestrian street environment and suggesting upgrading for solving the problems. Various studies proved the PLOS usefulness in assessing street facilities by considering attractiveness, safety, and convenience design factors, such as slope, sidewalk width, material, and surface condition (Asadi-Shekari et al., 2013a, 2014; Christopoulou and Pitsiava-Latinopoulou, 2012; Kang et al., 2013). However, despite the relevance of these assessment tools, they didn't consider thermal comfort in the walkability assessment. Thus, adding thermal comfort makes up an essential factor to be included in the PLOS.

From another perspective, an increasing number of studies focused on improving thermal comfort in outdoor urban spaces to enhance citizens' health, wellbeing and to promote outdoor activities (e.g., walkability, cycling). Moreover, thermal comfort defines the users' satisfaction level regarding the thermal environment (ASHRAE Standard, 2004; Potchter et al., 2018), based on the neutral temperature (Elnabawi et al., 2016).

Thermal comfort assessment requires combining meteorological variables with thermo-physiological parameters (Mayer, 1993; VDI, 1998). According to Potchter et al.(2018), the Physiological Equivalent Temperature (PET) (Matzarakis et al., 1999; Mayer and Höppe,1987) and the Universal Thermal Climate Index (UTCI) (Jendritzky, G et al., 2012) are the most used indexes for the assessment of outdoor thermal environments. PET had been applied and validated in several climates zones (Gulyás et al., 2006; Johansson et al., 2014; Matzarakis et al., 1999; Thorsson et al., 2007) as well as different outdoors environments (Ali-Toudert and Mayer, 2007; Andrade et al., 2011; Charalampopoulos et al., 2013; Knez and Thorsson, 2006; Lai et al., 2014; Lin et al., 2013; Lin and Matzarakis, 2008; Matzarakis et al., 2007; Thorsson et al., 2007). Many studies applied a numerical simulation model of the climatic variable at the street level (Acero and Herranz-Pascual, 2015; Klemm et al., 2015; Lee et al., 2016; Morakinyo et al., 2017) using software to optimize thermal comfort 
index accuracy. For example, ENVI-met and Rayman are well-known software used to calculate outdoor thermal comfort. Envi-met simulation allows predicting the mean radiant temperature $\left(\mathrm{T}_{\mathrm{mrt}}\right)$, relative humidity, air temperature, wind speed and surface temperature (Acero and Herranz-Pascual, 2015). These four microclimatic variables are essential to calculate outdoor thermal comfort, besides metabolic rate and clothing insulation (Watanabe et al., 2014).Thus, different scholars Cohen et al. (2013); Elnabawi et al. (2016); Kántor et al.(2012); Lai et al.(2014); Tseliou et al. (2010) combined simulation and field surveys in outdoor environments. To provide an extensive perspective concerning the impact of micro climate on outdoor thermal comfort and urban space use.

Based on the current literature, the thermal conditions of the walking environment have been under-investigated, despite the importance of the outdoor thermal environment for pedestrians. Indeed, thermal stress could debase the walking experience and indirectly hinder walkability and PLOS. Only a few recent studies associated walkability and thermal comfort. Lee et al. (2020) explored the influence of biometeorological related factors on pedestrian behavior by calculating PET and UTCI to express thermal stress in Hong Kong, China. The findings highlighted the correlation between thermal sensation and pedestrian choice of the shaded zone. However, the selected comfort indices have not been included in the walkability assessment. Labdaoui et al. (2021) developed a measurement tool by considering PET as a walkability indicator in the Csa climate. However, despite considering climatic variables such as air temperature, wind velocity, and relative humidity, the $\mathrm{T}_{\mathrm{mrt}}$ was not included in the PET assessment. This paper fills this knowledge research gap by proposing the Street Walkability and Thermal Comfort Street Index (SWTCI). This innovative method is based on PLOS system that combines thermal comfort and walkability at the street scale. 
The current study aims to measure walkability at the street level by considering pedestrian comfort-related facilities and thermal comfort. For this purpose, we developed a new assessment tool, the Street Walkabilllity and Thermal Comfort Index (SWTCI). The presented method comprises some main steps that are summarised in Fig 1. The first one is reviewing effective indicators to identify pedestrian facilities and thermal comfort variables in research papers and standard guidelines, using Google Scholar, the Web of Science. Keywords included walkability, thermal comfort, street, Envi-met, simulation, assessment tools, street's furniture policy, and Csa. This research was conducted between 2002 and 2019 to select all the indicators that improve the walking experience. The finding emphasizes the lack of consideration for thermal comfort in the walkability assessment at the street scale. The microclimatic variables are also missing in the evaluation of walkability comfort.
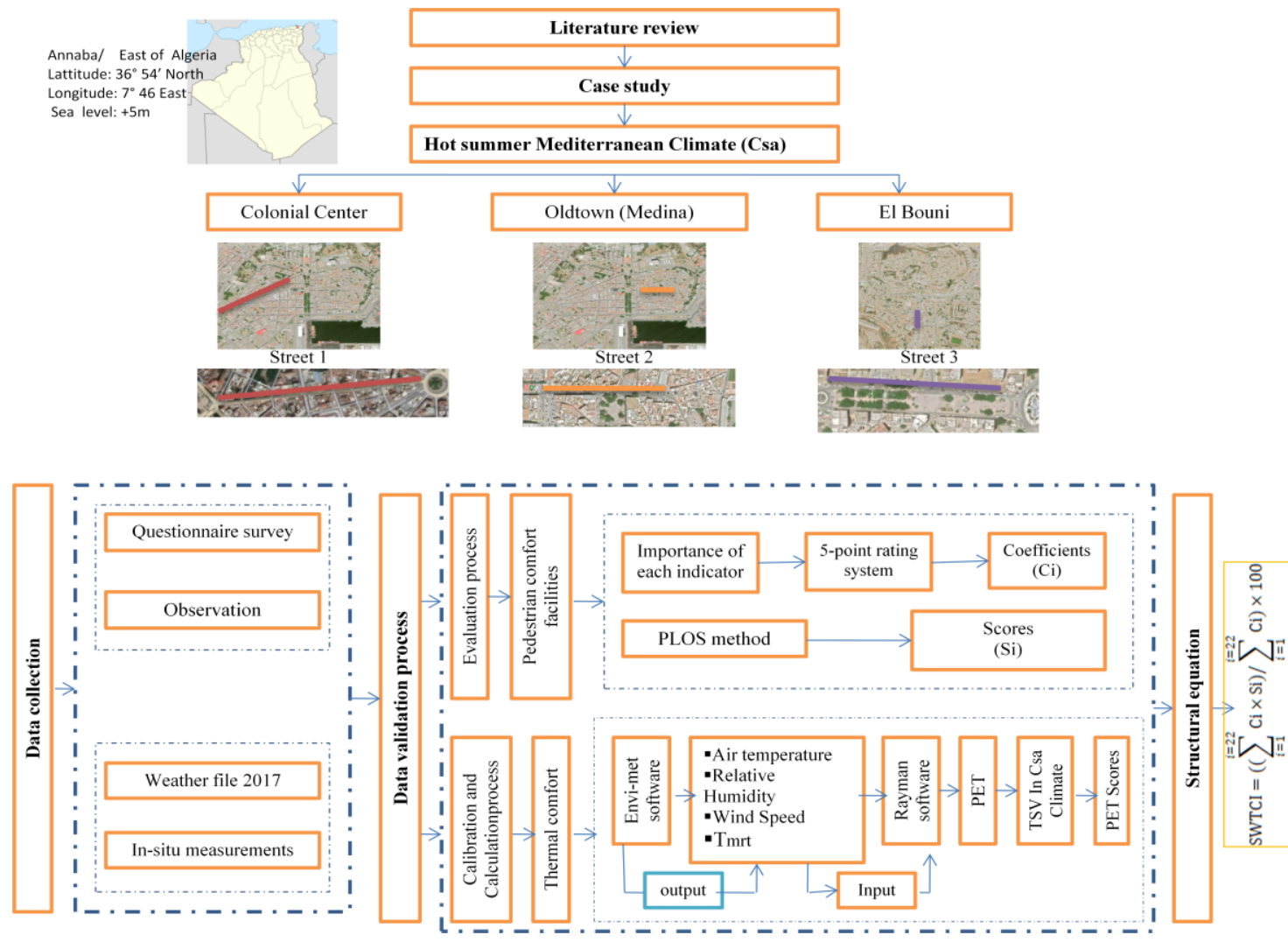

Fig.1.Conceptual framework of the STWCI 
Table 1 Pedestrian comfort facilities on street level

\begin{tabular}{ll}
\hline \multicolumn{1}{c}{ Pedestrian comfortfacilities } & \multicolumn{1}{c}{ References } \\
\hline Slower traffic speed & Asadi-Shekari et al. 2015, 2014; Lee and Kim, \\
& 2019; Retting et al. 2003) \\
Buffer and barriers (curb and furnishing zone) & Asadi-Shekari et al. 2015; Jaskiewicz 2000; \\
& Labdaoui et al. 2021 \\
Fewer traffic lanes, & Asadi-Shekari et al., 2015, 2014; Labdaoui et al. \\
& 2021 \\
Mid-block crossing & Diogenes and Lindau, 2010; King et al. 2009 \\
Landscape and tree & Aghaabbasi et al. 2019; Labdaoui et al. 2021; Lee et \\
& al. 2016; Todorova et al. 2004 \\
Furniture (trash receptacles) & Aghaabbasi et al. 2019, 2017; Asadi-Shekari et al. \\
& 2019, 2014; Labdaoui et al. 2021 \\
Footpath pavement & Kelly et al. 2011; Moura et al. 2017; Nilles and \\
& Kaparias, 2018 \\
Marking (crosswalk) & Kelly et al. 2011; Labdaoui et al. 2021; Moura et al. \\
& 2017; Ruiz-Padillo et al. 2018 \\
Sidewalk on bothsides & Asadi-Shekari et al. 2015; Cain et al. 2014; \\
& Labdaoui et al. 2021 \\
Width of footpath & Landis et al. 2001; Nilles and Kaparias, 2018 \\
Slope & Asadi-Shekari et al. 2014; Kim et al. 2014; Koh and \\
& Wong, 2013; Labdaoui et al. 2021 \\
Lighting & Asadi-Shekari et al. 2019; Crews and Zavotka, \\
& 2006; Nilles and Kaparias, 2018 \\
Ramp & Aghaabbasi et al. 2019; Christopoulou and Pitsiava- \\
Park and space for playing & Latinopoulou, 2012 \\
& Gehl et al. 2006; Labdaoui et al. 2021; Lamour et al. \\
Social space (café) & 2019 \\
& Gunn et al. 2017; Koh and Wong, 2013; Labdaoui \\
Shade & et al. 2021; Moura et al. 2017 \\
& Clifton et al., 2007; Jaskiewicz, 2000; Taleai and \\
Bench and seating area & Taheri Amiri, 2017 \\
Toilet & Asadi-Shekari et al. 2019; Galanis and Eliou, 2011; \\
& Kihl et al. 2005; Troped et al., 2006 \\
Pedestrian signal & Aghaabbasi et al. 2018; Asadi-Shekari et al. 2019; \\
& Labdaoui et al. 2021 \\
Shorter crossing distance (curb extension) & Aghaabbasi et al. 2018; Asadi-Shekari et al. 2014; \\
& Boisseau, 1999 \\
& Asadi-Shekari et al. 2015; Johnson, 2005; Labdaoui \\
& et al. 2021 \\
\hline & \\
\hline & \\
&
\end{tabular}


to measure the importance of pedestrian facilities according to people's perceptions. It included general information (age, gender, education) and highlighted street facilities' importance. People were asked to classify the importance of the selected indicators according to a scale of less important (1) to very important (5). Before the accurate data collection in June-august 2019, a pilot test with ten persons was carried out to verify the process and ensure the straightforwardness and clarity of all questions. The sample size is 330 , based on the city population of 640,050 , with a $95 \%$ confidence level and $5.4 \%$ margin of error. The survey's main purpose was to estimate the importance of pedestrian comfort features in general and not specially related to a specific street.

\subsection{Microclimatic measurements}

Three different streets were selected according to the following criteria: street morphology, slight slope, buildings' height, street orientation, length of the sidewalk, vegetative species, and distribution. We used microclimate monitoring instruments LM 8000 (Thermo-Anemometer, Hygrometer, Thermometer \& Illuminometer) at the height of $1.10 \mathrm{~m}$ from the ground, at specific points on the $26^{\text {th }}$ and $28^{\text {th }}$ of August 2017. Air temperature (Ta), relative humidity $(\mathrm{Rh})$, and wind speed $(\mathrm{v})$ were measured and recorded at the one-second interlude. The measurement precision of microclimatic variables was $\pm 0.2{ }^{\circ} \mathrm{C}, 3 \%(\%)$ and $0.2(\mathrm{~m} / \mathrm{s})$. Every street has a specific measurement point near the sidewalk border to reduce the effect of unmeasured parameters and curtail interference with pedestrian observation and behavior. Finally, the third step involves the assessment of street facilities and PET.

To estimate these indicators, we calculated the coefficients using the survey results, scores with observation results, and PET based on the in situ measurement (to validate simulation by Envi-met tool and to get $\left.\mathrm{T}_{\mathrm{mrt}}\right)$. The calibration process results allowed air temperature, wind speed, relative humidity, and $\mathrm{T}_{\mathrm{mrt}}$ considered in the PET calculation with 
Table 2 CWTCI \% interpretation Eq (1) (Labdaoui et al., 2021) : scores.
158

the RayMan program. The SWTCI is based on the PLOS method. It can be calculated from

$$
\text { SWTCI }=\left(\left(\sum_{i=1}^{i=22} \mathrm{Ci} \times \mathrm{Si}\right) / \sum_{i=1}^{i=22} \mathrm{Ci}\right) \times 100 \ldots \ldots \ldots \ldots . . . \mathrm{Eq} .(1)
$$

Where Ci: Coefficient of each indicator, Si: Score of each indicator.

Table 2 shows the suggested categories of (SWTCI) from A to F,in line with other point system studies related to pedestrians(Aghaabbasi et al., 2017; Asadi-Shekari et al., 2014; Moeinaddini et al., 2015). Thus, class (A) presents the highest comfort quality with 80100 scores while the $(\mathrm{F})$ category is the lowest class, estimated very uncomfortable with 1-19

\begin{tabular}{lll}
\hline $\begin{array}{l}\text { SWTCI \% } \\
\text { rating }\end{array}$ & $\begin{array}{l}\text { Model } \\
\text { score }\end{array}$ & Interpretation \\
\hline A & $80-100$ & $\begin{array}{l}\text { The highest quality (very comfortable); reflecting the existence of many } \\
\text { comfort pedestrian facilities. }\end{array}$ \\
B & $60-79$ & $\begin{array}{l}\text { High-quality (acceptable), some comfort pedestrian facilities present. } \\
\text { Average quality (rarely comfortable), pedestrian comfort facilities present. }\end{array}$ \\
C & $40-59$ & $\begin{array}{l}\text { However, the potential to improve pedestrian comfort conditions is } \\
\text { omnipresent. }\end{array}$ \\
D & $20-39$ & $\begin{array}{l}\text { Low-quality (uncomfortable), minimal pedestrian facilities. } \\
\text { E }\end{array}$ \\
F & $1-19$ & $\begin{array}{l}\text { Lowestquality (unpleasant). } \\
\text { There are no standard pedestrian amenities (very uncomfortable). }\end{array}$
\end{tabular}

\subsection{Sidewalk measurement in the pedestrian level of service (PLOS) methods}

Pedestrian level of service (PLOS) methods are extensively used in urban and transportation models. The macro and micro design methods are relevant in measuring pedestrian environments (Aghaabbasi et al., 2017). Although the micro design factors are crucial to analyze the walking environment's quality (Asadi-Shekari et al., 2019; Southworth, 
2005), many existing PLOS models explored just the macro-scale approach. The latter approach considers macro design factors such as density, diversity, design, destination accessibility, and distance to transit (Kim et al., 2014).

Since the current study's scope is street level, the focus is on PLOS models at the street scale (considering micro design factors). These PLOS models have different techniques and characteristics. However, each one has its benefits and drawbacks regarding sidewalk measurement. Fig 2 shows the primary types of indicators and scopes included in these PLOS models for the sidewalk assessment.

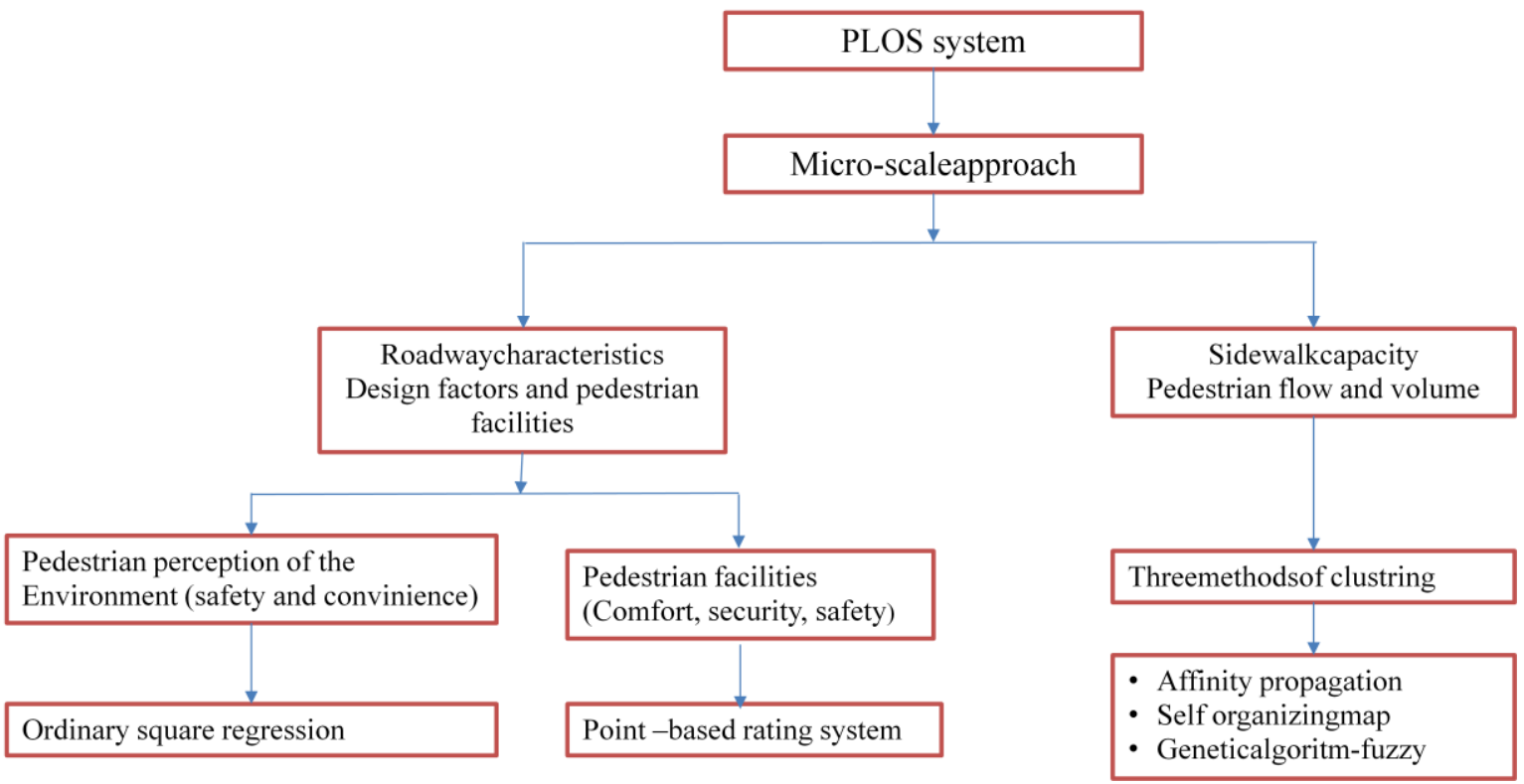

Fig. 2. Main scopes for PLOS models at the street level (Asadi-Shekari et al., 2013)

Some studies characterized the PLOS as a classification question. For example, Sahani and Bhuyan (2014) investigated three clustering methods, counting affinity propagation, self-coordinating map in artificial neural networks, and genetic algorithm-fuzzy (GA-Fuzzy) approach. Despite clarifying that GA-Fuzzy the most relevant clustering, this method only focused on capacity and met some related indicators such as pedestrian space, flow, volume to capacity ratio, and pedestrian speed, rather than the principal aim of PLOS for sidewalk facilities (Asadi-Shekari et al., 2019). 
According to Asadi-Shekari et al.(2019), the PLOS method at the street level could be categorized into two major categories (Asadi-Shekari et al., 2013b, 2013a). The first category includes capacity-based tools that concentrate on sidewalk capacity, pedestrian flow, and volume. Ignoring micro-level design factors in walkability evaluation (e.g., Fruin, 1971; Manual, 2000), such as curb ramp, accessible drinking fountain, lighting, seating area, landscape, and trees. The second category includes the roadway aspects-based model that emphasizes design factors and pedestrian facilities (e.g., Asadi-Shekari et al., 2014, 2013b, 2013a; Landis et al., 2001; Sarkar S., 1993; Tan et al., 2007). The first method was criticized because pedestrians were comparable to cars and not users with special needs (Asadi-Shekari et al., 2013b, 2013a). Therefore, the second approach is more suitable for measuring walkability based on comfort-related factors that focus on this study.

Miller et al. (2000) suggested a point system in their PLOS evaluation. However, the restrained number of street facilities and users was inadequate for assessing inclusive streets. Landis et al. (2001) and Jensen (2007)explored more street factors to measure the PLOS. However, they applied an ordinary squares regression and found a few significant indicators that exclude people with disabilities. Asadi-Shekari et al. (2013b) suggested a point system as a suitable method for their PLOS model to explore micro-level design factors for all people, including people with disabilities. Although they consider weights and different measurement scores to include all possible conditions and avoid subjectivity in their evaluation, they did not consider PET in their proposed point system.

\subsection{Thermal comfort indices}

We selected PET to represent thermal comfort because it was applied and validated in multiple climates and urban areas (Gulyás et al., 2006; Johansson et al., 2014; Matzarakis et al., 2007; Thorsson et al., 2007) based on field surveys (Elnabawi et al., 2016; Lin et al., 2013; Nikolopoulou et al., 2001; Nikolopoulou and Lykoudis, 2006). Besides, PET was 
associated with the Mean Thermal Sensation Vote (MTSV) within the hot and cold climate. Therefore, the assignment scores of PET are related to the human thermal sensation scale in the Mediterranean climate based on Potchter et al. (2018) findings.

Many studies explored PET based on in situ measurements using Envi-met or RayMan software. The Envi-met model is a three-dimensional micro-meteorological program (Bruse and Fleer, 1998) and is considered one of the few micro-scale models that meet the required precise simulation standards. It verifies the correlation between the physical processes and the resulting micro-meteorological conditions in the urban canopy and thermal boundary layer (Lee et al., 2016). Also, it has been applied in simulations of the micro-climate and humanbio-meteorological influence of street design, building, and urban greening (Ali-Toudert and Mayer, 2007, 2006; Lee et al., 2016). Therefore, Envi-met was used in our study to calibrate data and get the Mean radiant temperature $\left(\mathrm{T}_{\mathrm{mrt}}\right)$.

RayMan is considered one of the most successful radiations and bio-climate models (Cohen et al., 2013; Elnabawi et al., 2016). This software was developed according to the German Engineering Society's guidelines (VDI, 1998), University of Freiburg, Germany. It assesses PET according to different parameters (e.g., air temperature, air humidity, wind velocity, cloud cover, time of the day and year), and human clothing ( 0.9 clo), and activity (80 W) (Matzarakis et al., 2010, 2007).

Few studies combined the two programs to get more accurate results. Recent works adopt this approach in distinct outdoor environments (e.g., streets, parks, squares) within different climate zones, despite their rarity in the Mediterranean climate (Table 3). 
Table3 Overview of PET calculations method in outdoor environments

\begin{tabular}{|c|c|c|c|c|c|}
\hline Authors & Thermal comfort indices & Area/climate & Urbanlayout & $\begin{array}{l}\text { Climatic } \\
\text { /Microclimaticindicators }\end{array}$ & Method \\
\hline $\begin{array}{l}\text { Andreou, } \\
2013\end{array}$ & PET & Tinos, Greece & $\begin{array}{l}\text { Streets } \\
\text { (geometry, orientation) }\end{array}$ & Basic meteorological data & $\begin{array}{l}\text { Calculation of PET using the Rayman v.1.2 } \\
\text { tool } \\
\text { Calculation of } \mathrm{T}_{\mathrm{mrt}} \\
\text { Calculation Solar access and shading } \\
\text { Calculating PET }\end{array}$ \\
\hline \multirow[t]{2}{*}{$\begin{array}{l}\text { Salata et al. } \\
2016\end{array}$} & PET & $\begin{array}{l}\text { The Mediterranean } \\
\text { climate, Csa }\end{array}$ & Street, square. & In-situ measurements & Calculating $\mathrm{T}_{\mathrm{mrt}}$ \\
\hline & & & & & Questionnaire for (MTSVs) \\
\hline $\begin{array}{l}\text { Klemm et } \\
\text { al. } 2015\end{array}$ & PET & Netherlands & $\begin{array}{l}\text { Parks } \\
\text { (size, tree canopy, } \\
\text { upwind } \\
\text { vegetation cover) }\end{array}$ & In-situ measurements & $\begin{array}{l}\text { PET Calculation using Rayman software. } \\
\text { Calculating } \mathrm{T}_{\mathrm{mrt}} \\
\text { Questionnaire for inhabitants' long-term } \\
\text { perception of thermal comfort on warm } \\
\text { summer days }\end{array}$ \\
\hline $\begin{array}{l}\text { Taleghani } \\
\text { and Berardi, } \\
2018\end{array}$ & PET & Toronto & square & $\begin{array}{l}\text { Climatic data } \\
\text { In-situ measurements }\end{array}$ & $\begin{array}{l}\text { ENVI-met simulations } \\
\text { Simulated results (Air temperature, } \mathrm{T}_{\mathrm{mrt}} \text { and } \\
\text { surface temperature) }\end{array}$ \\
\hline $\begin{array}{l}\text { Liu et al. } \\
2016\end{array}$ & PET & Changsha, China & $\begin{array}{l}\text { Park, square, grassland, } \\
\text { 3kind of the sidewalk. }\end{array}$ & In-situ measurements & $\begin{array}{l}\text { PET Calculation using Rayman software. } \\
\text { Surveys during } 4 \text { seasons }\end{array}$ \\
\hline $\begin{array}{l}\text { Lee et al. } \\
2016\end{array}$ & PET & Freiburg, Germany & Residential district & $\begin{array}{l}\text { In-situ measurements } \\
\text { Climatic data }\end{array}$ & $\begin{array}{l}\text { PET and } \mathrm{T}_{\text {mrt }} \text { are calculated using } \\
\text { ENVI-met } \\
\text { Calculating PET using Ravman }\end{array}$ \\
\hline $\begin{array}{l}\text { Cohen et al. } \\
2013\end{array}$ & PET & $\begin{array}{l}\text { The Mediterranean } \\
\text { climate }\end{array}$ & Park, Square, Street & In-situ measurements & $\begin{array}{l}\text { Calculating PET using Rayman } \\
\text { Statistical data analysis of the in-situ } \\
\text { Subjective thermal sensation voter records on } \\
\text { the questionnaires with PET values }\end{array}$ \\
\hline $\begin{array}{l}\text { Elnabawi et } \\
\text { al. } 2016\end{array}$ & PET & $\begin{array}{l}\text { Hot Arid Climate of } \\
\text { Egypt }\end{array}$ & $\begin{array}{l}\text { Streets } \\
\text { In Medieval Cairo }\end{array}$ & In-situ measurements & $\begin{array}{l}\text { Calculating PET using Rayman } \\
\text { Subjective thermal sensation records the } \\
\text { questionnaires with PET values }\end{array}$ \\
\hline $\begin{array}{l}\text { Morakinyo } \\
\text { et al. } 2017\end{array}$ & PET & Hong Kong & Street canyon. & In-situ measurements & $\begin{array}{l}\text { Calculating PET using Rayman } \\
\text { Calculating } \mathrm{T}_{\text {mrt }} \text { using Envi-met software } \\
\text { Shades ENVI-met simulations, its impact on } \\
\text { thermal comfort }\end{array}$ \\
\hline
\end{tabular}


The main aim of this study is the application of the SWTCI at different street

morphologies. The survey is also designed to estimate the importance of the indicators for available street types. However, for particular street types like tiny streets, some indicators such as slower traffic speed, marking (crosswalk), mid-block crossing, and slower traffic speed, could be freeze. Therefore, the proposed method can be used for general street types in different cities and particular streets and cities. The included indicators and weights need to be justified and localized.The SWTCI within Csa is applied according to the following method.

\subsection{Assessing indicators}

One of the main limitations for PLOS point systems like Asadi-Shekari et al. (2013b)is ignoring the perceptions and PET. This study fills this gap by using people's perceptions and viewpoints as weights and coefficients for the indicators and including the PET effects. In addition, a series of in situ observations is also used to evaluate each comfort indicator's state objectively and measure their scores (Asadi-Shekari et al., 2014).

\subsubsection{Pedestrian comfort facilities coefficients and scores}

The questionnaire survey measured 21 street design indicators' importance, using a five-point Liker scale ranging from 1 (least important) to 5 (very important). This survey explored people's perceptions regarding the matter of pedestrian facilities. In total, 330 respondents in Annaba completed the survey online. The survey data are used to achieve each comfort indicator's relative weight (coefficient) (Cis).

Using the observation technique seeks to quantify every pedestrian comfort indicator as a score (Sis), indicating a number between 0 and 1 . The score (1), considered the best score, reveals a relevant match between the existing street condition and the guideline requirements. In contrast, the score (0) means no link or the indicator is not existing in the 
case study. There are also some scores between 0 and 1 to cover the semi-fitness situations.

252 For more details, refer to Appendix A and B.

253

254

255

256

257

258

259

260

261

262

263

264

265

266

267

\subsubsection{Calculating and scoring PET}

To understand thermal comfort impact on pedestrians, PET was computed on the selected streets using RayMan (Matzarakis et al., 2010, 2007). This study also used the spatial height performance and temporal microclimate resolution model, the Envi-met 4 software that can generate simulations by designing the building's architecture and vegetation model (Wu and Chen, 2017). Before PET calculation, the $\mathrm{T}_{\mathrm{mrt}}$ was measured through the calibration process using the full forcing command (24h) with Annaba weather records data $\left(26^{\text {th }}\right.$ and $28^{\text {th }}$ of August 2017).

We validated the calibrated model based on the difference between simulated and measured air temperature, which showed a good performance between the two data sets (Elnabawi et al., 2013; Taleghani and Berardi, 2018) $\mathrm{Y}=0.862 \mathrm{x}+3.909, \mathrm{R}^{2}=0.84$ (Fig3). Consequently, we got four calibrated data: air temperature, wind velocity, relative humidity, and $\mathrm{T}_{\mathrm{mrt}}$. Therefore, based on these calibrated data (Klemm et al., 2015; Lobaccaro and Acero, 2015; Morakinyo et al., 2017; Taleghani and Berardi, 2018), we calculate PET from 8 am to 8 pm (Fig 1). 


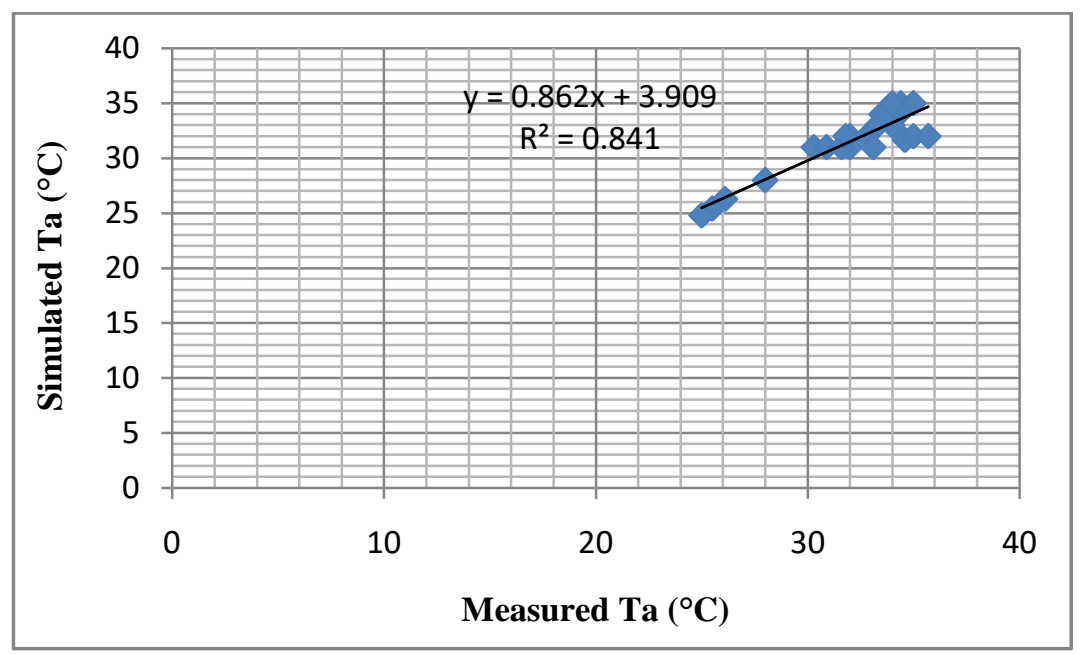

Fig.3. Correlation between simulated and measured air temperature.

To score PET in the Mediterranean climate, we applied a scale from 0 to

2721 (Labdaoui et al., 2021), considering the defined thermal sensation vote (TSV) in Tel Aviv,

273 characterized by a Csa. Thus, despite the same climate classification, both cities have the

274 same level from the sea $+5 \mathrm{~m}$. According to Potchter et al. (2018), the thermal comfort range

275 in TelAviv is between $19^{\circ} \mathrm{C}-25^{\circ} \mathrm{C}$ in winter and $20^{\circ} \mathrm{C}-26^{\circ} \mathrm{C}$ in summer. Therefore, for cold,

276 hot, and very hot thermal sensations, the PET score is 0. For cool and warm thermal

277 perception, the score is 0.25 ; for slightly cool and slightly warm, the score is 0.5 . Finally, the

neutral thermal sensation reaches the score of 1 . (Refer to Tables 4 and 5).

Table 4 Thermal sensation and PET range for Tel Aviv (Csa climate) (Cohen et al., 2013; Lin and Matzarakis, 2008; Matzarakis et al., 1999; Potchter et al., 2018)

\begin{tabular}{llll}
\hline TSV & Thermal sensation & $\begin{array}{l}\text { PET range } \\
\text { for Tel Aviv }\left({ }^{\circ} \mathrm{C}\right)\end{array}$ & $\begin{array}{l}\text { Tel AvivClimatic zone } \\
\text { (Koppen classification) }\end{array}$ \\
\hline-4 & Very cold & - & \\
-3 & Cold & 8 & \\
-2 & Cool & 12 & Csa \\
-1 & Slightly cool & 15 & \\
0 & Neutral & 19 & \\
1 & Slightly warm & 26 & \\
2 & Warm & 28 & \\
3 & Hot & 34 & \\
4 & Very hot & 40 & \\
\hline
\end{tabular}

${ }^{\mathrm{a}}$ Vote scale (TSV), Warm Mediterranean Climate (Csa). 
Table 5 PET scores according to the Thermal sensation and PET range in Csa Climate (Labdaoui et al., 2021).

285

286

287

288

289

290

291

292

293

294

295

296

297

298

299

300

301

302

303

\begin{tabular}{cc}
\hline PET range & PET scores \\
\hline$>8^{\circ} \mathrm{C}$ & 0 \\
$8^{\circ} \mathrm{C}-12^{\circ} \mathrm{C}$ & 0.25 \\
$12.1^{\circ} \mathrm{C}-15^{\circ} \mathrm{C}$ & 0.5 \\
$19.1^{\circ} \mathrm{C}-26^{\circ} \mathrm{C}$ & 1 \\
$26.1^{\circ} \mathrm{C}-28^{\circ} \mathrm{C}$ & 0.5 \\
$28.1^{\circ} \mathrm{C}-34^{\circ} \mathrm{C}$ & 0.25 \\
$34.1^{\circ} \mathrm{C}-40^{\circ} \mathrm{C}$ & 0 \\
\hline
\end{tabular}

\subsection{Case Study}

The field study was conducted in Annaba city, Algeria, located between (Lattitude $36^{\circ} 54^{\prime}$ North, Longitude: $7^{\circ} 46^{\prime}$ East, Sea level: $\left.+5 \mathrm{~m}\right)$. Annaba is defined by the Hot Summer Mediterranean climate (Csa), according to Köppen (2020) classification. Annaba city gathers a population of 640,050 inhabitants, according to The National office of statistics (2008). We selected three different streets in three diverse neighborhoods in Annaba city (Fig 4). The first segment in Colonial Centre is a regular and furnished street (Having minimum pedestrian features) with North-East, South-West orientation, and $\mathrm{h} / \mathrm{w}=2$. The second case in the medieval neighborhood (Medina) with East West orientation has an irregular morphology and has a ratio $\mathrm{h} / \mathrm{w}$ equivalent to 1.83 . The last street was in El Bouni neighborhood (Suburban area), with a North-South direction characterized by a regular morphology with $\mathrm{h} / \mathrm{w}=0.29$, but it is unfurnished (Table 6). These selections are just for testing the proposed STWCI in different types of streets, and the proposed STWCI can be used to measure walkability for other streets. 
Table 6 The characteristics of the selected streets

\begin{tabular}{cccc}
\hline Streets' characteristics & Street1 & Street2 & Street3 \\
\hline Length & $512.9 \mathrm{~m}$ & $323.22 \mathrm{~m}$ & $299.68 \mathrm{~m}$ \\
Orientation & NE/SW & $\mathrm{E} / \mathrm{W}$ & $\mathrm{N} / \mathrm{S}$ \\
High of building & $16 \mathrm{~m}$ & $11 \mathrm{~m}-13 \mathrm{~m}$ & $12 \mathrm{~m}-15.5 \mathrm{~m}$ \\
Ratio h/w & 2 & 1.83 & 0.29 \\
Vegetative elements (Trees) & 0 & 3 & 0 \\
Building's material & stones & Stones/Solid & Precast concrete walls \\
Building's color & White & bricks & Yhite \\
Footpath material & Pavement & Concrete & Unfurnished+ concrete \\
& & & stranded tiles. \\
\hline
\end{tabular}

305

NE/SW: North East/South West, E/W: East/West, N/S: North/South

306

307

308

309

310

311 


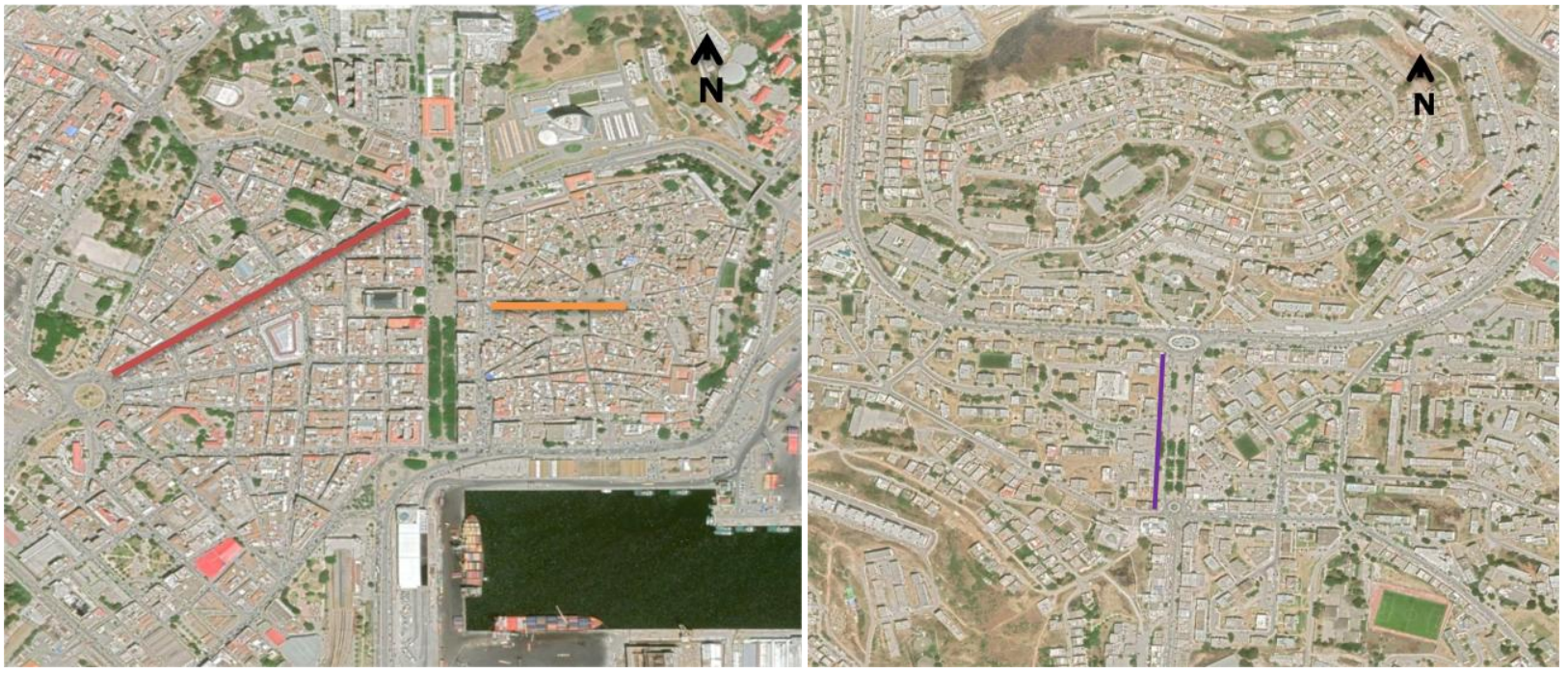

- Street 1 in Colonial Center, - Street 2 in Medieval neighbourhood, — Street3 in El Bouni
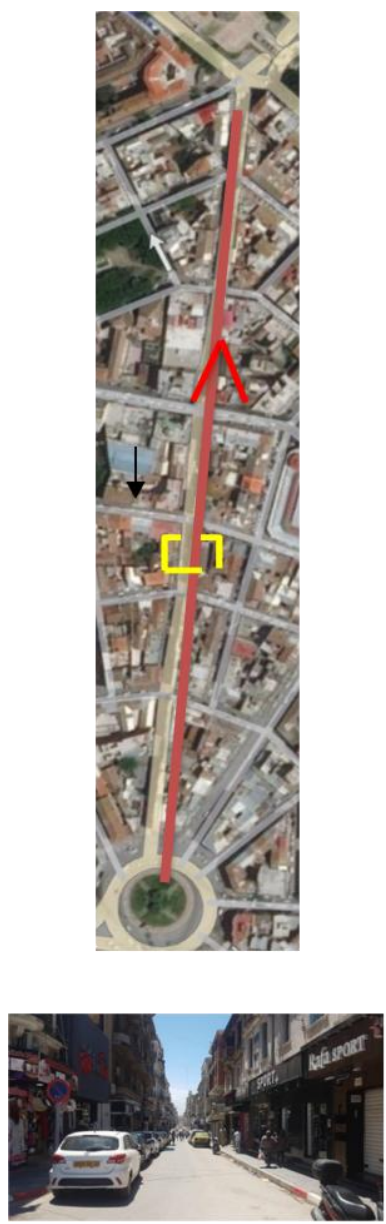
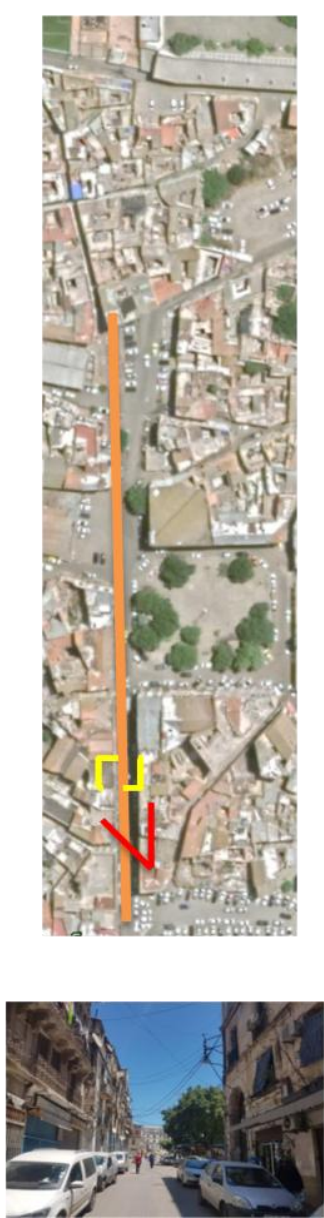
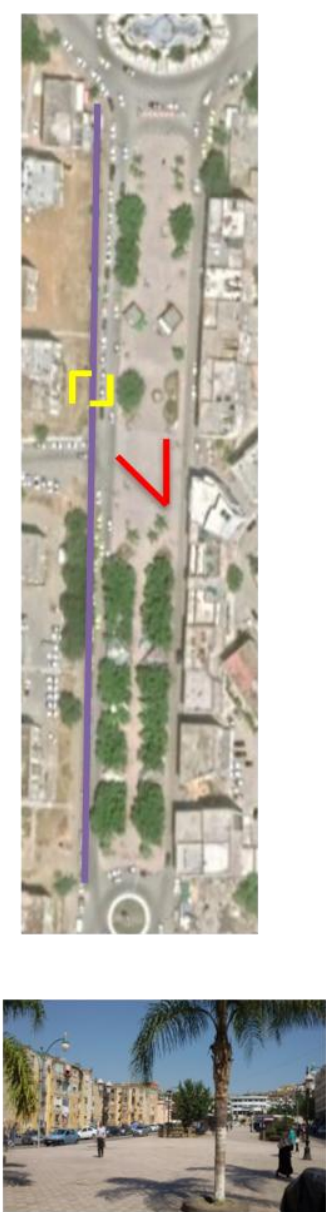

315 Fig.4. Location of selected streets at three distinct neighbourhoods. 


\section{Results}

\subsection{Pedestrian comfort facilities coefficients and observation scores}

\subsubsection{Sample characteristics}

The sample comprised 330 respondents, 53\% male and $47 \%$ female. Some age categories were more involved than others. The results showed $64 \%$ of the response are related to the 25-34 category, followed by the 35-44 years group. In comparison, the youngest group (18-24 years old), and 45-54 years and 55-64 years, represented only 8\%, 3\%, 5\% survey responses. Two categories, 65-74 years and +75 years old, didn't take part in the survey. Since this survey's main purpose is to estimate just the importance of the indicators, the scores are calculated using objective measurement methods. Therefore, the differences in age categories, mainly because of the online data collection, cannot affect the scores. In addition, the 25-44 age categories can represent the majority of the pedestrian population in the city, and the estimated weights can represent the opinions of the majority of the pedestrian population.

\subsubsection{Coefficient results}

The first column in Table 6 presents the coefficients of comfort walkability indicators. Over $95 \%$ of the suggested factors such as landscape and trees, footpath pavement, shade, bench and seating area, and social space(café) are considered very important and highly significant $(0.80$ and 0.93$)$. Other indicators such as the ramp, pedestrian signals, footpath width, and slope are estimated as essential (0.67-0.77). However, a single indicator (trash receptacle) was supposed less critical, having a score of 0.32 .

\subsubsection{Observation scores result}

From the data presented in the second column of Table 7, six pedestrian comfort indicators had a score of 1 . This value demonstrated an actual presence of factors on the streetlin Colonial center (e.g., social space (café), the sidewalk on both sides, slower traffic 
speed, few traffic lanes). On the other hand, footpath pavement, the width of the footpath, and buffer/barriers (curb and furnishing zone) has $0.8,0.8$, and 0.5 scores, respectively, estimated present on the street. Still, they are not meeting the recommended standard. However, a score of 0 suggests the non-existence of the pedestrian comfort facilities in the street segment.

The third column shows the observation scores of Street 2 in the medieval neighborhood (medina). The highest score (1) is assigned to social space (café), slower traffic speed, few traffic lanes, so they are available and correspond to the referred methodological calculations. Alternatively, the ramp and standard driveway are not existing in the street. Other indicators to which scores are $0.13,0.12$ reflect no weight (e.g., footpath pavement and width of the footpath). In comparison, the sidewalk on both sides and buffer/barriers (curb and furnishing zone) indicators, with respectively 0.39 and 0.5 scores, highlight a failure with the required standards. However, the rest of the comfort walkability indicators having a score equivalent to 0 showed their total absence on the street.

The last column exhibits the observation scores at street 3 (El Bouni neighborhood). Most of the street comfort facilities had a 0 score, reflecting their lack on the street. Other indicators such as buffer and barriers, having a score of 0.5 , indicated a deficiency with the recommended standard. However, social space (café), slower traffic speed, fewer traffic lanes scored the highest value 1, which implies their standard appearance on the street, while ramp and standard driveway are not available. 
Table7 The scores and coefficients of street comfort indicators

\begin{tabular}{|c|c|c|c|c|}
\hline & & Street1 & Street2 & Stree3 \\
\hline & \multirow[t]{2}{*}{ Length } & $512.9 \mathrm{~m}$ & $323.22 \mathrm{~m}$ & $299.68 \mathrm{~m}$ \\
\hline & & NE/SW & East/West & $\mathrm{N} / \mathrm{S}$ \\
\hline \multicolumn{5}{|c|}{ Orientation } \\
\hline Indicators & Coefficients & Scores & Scores & Scores \\
\hline Landscape and trees & 0.93 & 0 & 0.13 & 0 \\
\hline Footpath pavement & 0.93 & 0.8 & 0.12 & 0 \\
\hline \multirow{4}{*}{$\begin{array}{l}\text { Marking (crosswalk) } \\
\text { Park and space for } \\
\text { playing }\end{array}$} & 0.85 & 0 & 0 & 0 \\
\hline & 0.85 & 0 & 0 & 0 \\
\hline & \multirow{7}{*}{0.85} & 1 & 1 & 1 \\
\hline & & 1 & 1 & 1 \\
\hline \multirow{5}{*}{ Shade/Thermal comfort } & & 0.5 & 0.5 & 0.25 \\
\hline & & 0.25 & 0.25 & 0.5 \\
\hline & & 0.25 & 0.25 & 0.25 \\
\hline & & 0.5 & 0.5 & 0.25 \\
\hline & & 1 & 1 & 1 \\
\hline Benches and seating area & 0.84 & 0 & 0 & 0 \\
\hline Toilet & 0.82 & 0 & 0 & 0 \\
\hline $\begin{array}{l}\text { Buffer and barriers (curb } \\
\text { and furnishing zone) }\end{array}$ & 0.81 & 0.5 & 0.5 & 0.5 \\
\hline Social space (café) & 0.8 & 1 & 1 & 1 \\
\hline Sidewalk on both sides & 0.8 & 1 & 0.39 & 0 \\
\hline Ramp & 0.77 & 1 & 1 & 1 \\
\hline Mid-block crossing & 0.76 & 0 & 0 & 0 \\
\hline Pedestrian signal & 0.76 & 0 & 0 & 0 \\
\hline Width of footpath & 0.75 & 0.8 & 0.12 & 0 \\
\hline $\begin{array}{l}\text { Shorter crossing distance } \\
\quad \text { (curb extension) }\end{array}$ & 0.73 & 0 & 0 & 0 \\
\hline Slower traffic speed & 0.72 & 1 & 1 & 1 \\
\hline Slope & 0.71 & 0 & 0 & 0 \\
\hline Lighting & 0.69 & 0 & 0 & 0 \\
\hline Fewer traffic lanes & 0.68 & 1 & 1 & 1 \\
\hline Standard driveway & 0.67 & 1 & 1 & 1 \\
\hline $\begin{array}{l}\text { Furniture and facilities } \\
\text { (trash receptacle) }\end{array}$ & 0.32 & 0 & 0 & 0 \\
\hline
\end{tabular}

NE/SW: North East/South West, E/W: East/West, N/S: North/South

\subsection{Thermal comfort results and scores}

It is essential to mention that PET was computed based on four calibrated

370 microclimatic data (Air temperature, Relative humidity, wind velocity, and Mean radiant

371 temperature) at the three selected streets on the $26^{\text {th }}$ and $28^{\text {th }}$ of August 2017 (Table 8). The

372 purpose of this study is to estimate PET for the general population and not individuals. 
373 Therefore, some parameters like clothing and activity are used to represent the general 374 population (clothing: 0.9 clo and activity: $80 \mathrm{~W}$ ).

375

376

377

378

379

380

381

382

383

384

385

386

387

388

389 
Table 8Microclimatic data and PET results using Envi-met and RayMan software.

\begin{tabular}{|c|c|c|c|c|c|c|c|c|c|c|c|c|c|c|c|}
\hline \multirow[b]{2}{*}{$\begin{array}{l}\text { Time } \\
(\mathrm{H})\end{array}$} & \multicolumn{4}{|c|}{ Calibrated data (Envi-met) } & \multirow{2}{*}{$\begin{array}{c}\text { RayMan } \\
\text { PET1 } \\
\left({ }^{\circ} \mathrm{C}\right)\end{array}$} & \multicolumn{4}{|c|}{ Calibrated data (Envi-met) } & \multirow{2}{*}{$\begin{array}{c}\text { RayMan } \\
\text { PET2 } \\
\left({ }^{\circ} \mathrm{C}\right)\end{array}$} & \multicolumn{4}{|c|}{ Calibrated data (Envi-met) } & \multirow{2}{*}{$\begin{array}{c}\text { RayMan } \\
\text { PET3 } \\
\left({ }^{\circ} \mathrm{C}\right)\end{array}$} \\
\hline & $\begin{array}{l}\text { Ta1 } \\
\left({ }^{\circ} \mathrm{C}\right)\end{array}$ & $\begin{array}{l}\mathrm{Rh} 1 \\
(\%)\end{array}$ & $\begin{array}{c}\mathrm{V} 1 \\
(\mathrm{~m} / \mathrm{s})\end{array}$ & $\begin{array}{c}\text { Tmrt1 } \\
\left({ }^{\circ} \mathrm{C}\right)\end{array}$ & & $\begin{array}{l}\text { Ta } 2 \\
\left({ }^{\circ} \mathrm{C}\right)\end{array}$ & $\operatorname{Rh} 2(\%)$ & $\begin{array}{c}\mathrm{V} 2 \\
(\mathrm{~m} / \mathrm{s})\end{array}$ & $\begin{array}{c}\mathrm{T}_{\mathrm{mrt}} 2 \\
\left({ }^{\circ} \mathrm{C}\right)\end{array}$ & & $\begin{array}{l}\text { Ta } 3 \\
\left({ }^{\circ} \mathrm{C}\right)\end{array}$ & $\begin{array}{l}\mathrm{Rh} 3 \\
(\%)\end{array}$ & $\begin{array}{l}\text { V } 3 \\
(\mathrm{~m} / \mathrm{s})\end{array}$ & $\begin{array}{l}\mathrm{T}_{\text {mit }} \\
\left({ }^{\circ} \mathrm{C}\right)\end{array}$ & \\
\hline 8:00 AM & $\begin{array}{l}25.2- \\
25.3\end{array}$ & $\begin{array}{l}\text { below } \\
94 \%\end{array}$ & $\begin{array}{c}0.2- \\
0.4\end{array}$ & $\begin{array}{l}13.3- \\
13.5\end{array}$ & 20.1 & $\begin{array}{l}24.9- \\
25.1\end{array}$ & $96 \%$ & $0.3-0.4$ & $13.6-13.8$ & 20 & 26 & $48 \%$ & 0 & 12.8 & 19.9 \\
\hline 10:00 AM & $\begin{array}{c}30.5- \\
30.6\end{array}$ & $68 \%$ & $\begin{array}{c}0.5- \\
0.9\end{array}$ & $\begin{array}{c}17.7- \\
17.9\end{array}$ & 25.2 & $\begin{array}{c}30.5- \\
30.6\end{array}$ & $\begin{array}{c}\text { below } \\
73 \%\end{array}$ & $0.9-1.2$ & $18.3-18.5$ & 25.6 & 33.4 & $32 \%$ & 0 & 19.9 & 26 \\
\hline 12:00 PM & $31.6-32$ & $57 \%-59 \%$ & $\begin{array}{c}0.9- \\
1.9\end{array}$ & $18.7-19$ & 26.5 & $\begin{array}{l}31.1- \\
31.5\end{array}$ & $\begin{array}{l}58 \%- \\
61 \%\end{array}$ & $2-2.6$ & $19.1-19.3$ & 26.4 & 34.7 & $28.50 \%$ & 0.2 & 21.6 & 28.4 \\
\hline 2:00 PM & $\begin{array}{c}33.9- \\
34.2\end{array}$ & $71 \%$ & $\begin{array}{c}0.8- \\
1.5\end{array}$ & $\begin{array}{l}21.2- \\
21.5\end{array}$ & 29.4 & $\begin{array}{c}33.2- \\
33.5\end{array}$ & $\begin{array}{l}70 \%- \\
74 \%\end{array}$ & $1.6-1.9$ & $21.7-22$ & 29.5 & 31.6 & $50 \%$ & 2.4 & 20.5 & 27.3 \\
\hline 4:00 PM & $\begin{array}{c}34.6- \\
34.9\end{array}$ & $31 \%-32 \%$ & $1-2$. & $\begin{array}{l}23.9- \\
24.3\end{array}$ & 30.5 & $\begin{array}{l}34.3- \\
34.5\end{array}$ & $\begin{array}{c}\text { below } \\
33 \%\end{array}$ & $2.4-2.9$ & $24.5-24.8$ & 31 & 33.2 & $25 \%$ & 2.6 & 23.8 & 29.5 \\
\hline 6:00 PM & $31-31.2$ & $65 \%$ & $1-1.97$ & $\begin{array}{c}22.6- \\
22.8\end{array}$ & 27.5 & $\begin{array}{c}30.9- \\
31.1\end{array}$ & $\begin{array}{l}65 \%- \\
69 \%\end{array}$ & $2.1-2.5$ & $22.5-22.8$ & 26.6 & 31.6 & $44 \%$ & 0.5 & 23.6 & 28 \\
\hline 8:00 PM & $\begin{array}{l}27.5- \\
27.6\end{array}$ & $81 \%-83 \%$ & $\begin{array}{c}0.7- \\
1.4\end{array}$ & 19 & 23.6 & $\begin{array}{l}27.3- \\
27.4\end{array}$ & $\begin{array}{c}\text { below } \\
83 \%\end{array}$ & $1-1.3$ & $\begin{array}{l}\text { below } \\
19.07\end{array}$ & 23.1 & 28.8 & $57 \%$ & 0.5 & 20.1 & 24.8 \\
\hline
\end{tabular}

391

392 


\subsubsection{Microclimatic data}

397

398

399

400

401

402

403

404

405

406

407

408

409

410

411

412

413

414

415

416

417

418

419

The results show a significant difference in air temperature in the three streets. The lowest temperature was recorded in Street 2 (Medina) at 8 am, $24.9{ }^{\circ} \mathrm{C}$, compared to Street 1 $\left(25.2^{\circ} \mathrm{C}\right)$ and Street 3 with $26^{\circ} \mathrm{C}$. Although many hours reflected a high temperature $(12 \mathrm{pm}, 2$ pm, $4 \mathrm{pm})$, the $\mathrm{T}(\mathrm{a})$ at Streets 1 and 2 are similar at 10 am $\left(30.5^{\circ} \mathrm{C}-30.6^{\circ} \mathrm{C}\right)$. However, Street 2 showed the lower temperature at noon $\left(31.1^{\circ} \mathrm{C}-31.5^{\circ} \mathrm{C}\right), 2 \mathrm{pm}\left(33.2^{\circ} \mathrm{C}-33.5^{\circ} \mathrm{C}\right), 4 \mathrm{pm}$ $\left(34.3^{\circ} \mathrm{C}-34.5^{\circ} \mathrm{C}\right)$ in comparison to Street 1 with $\left(31.6^{\circ} \mathrm{C}-32^{\circ} \mathrm{C}\right),\left(33.9^{\circ} \mathrm{C}-34.2^{\circ} \mathrm{C}\right)$, and $\left(34.6^{\circ} \mathrm{C}\right.$ $\left.-34.9^{\circ} \mathrm{C}\right)$. At the same time, the highest temperature was recorded in Street 3 at noon $\left(34.7^{\circ} \mathrm{C}\right)$. Considering relative humidity, Streets 1 and 2 recorded a higher percentage during the entire hours of the day. For example, at 8 pm, Street 1 has (81\%-83\%), Street 2 (below 83\%) while Street 3 has $57 \%$ (Table 8).

The $\mathrm{T}_{\mathrm{mrt}}$ emphasized noticeable differences. The lowest values were recorded at 8 am for the three streets. For example, Street 1 has $13.3^{\circ} \mathrm{C}-13.5^{\circ} \mathrm{C}$, Street 2 recorded $13.6^{\circ} \mathrm{C}-$ $13.8^{\circ} \mathrm{C}$, and Street 3 has $12.8^{\circ} \mathrm{C}$. However, at noon, street 1 has a lower $\mathrm{T}_{\mathrm{mrt}}$ value than Street $2\left(19.1^{\circ} \mathrm{C}-19.3^{\circ} \mathrm{C}\right)$ and Street 3 with $21.6^{\circ} \mathrm{C}$. Finally, the wind velocity recorded common low values at the three streets (Table 8).

The PET values at Streets 1 and 2 are almost the same, especially during the hottest hours of the day. For example, at noon, the PET at Street 1 is $26.5^{\circ} \mathrm{C}$, compared to Street 2 $\left(26.4^{\circ} \mathrm{C}\right)$. However, at $8 \mathrm{pm}$, Street 2 recorded a lower temperature $\left(23.1^{\circ} \mathrm{C}\right)$ than Street 1 $\left(23.6^{\circ} \mathrm{C}\right)$. However, Street 3 registered the highest values of PET at all the hours of the day, compared to Street 1 and Street 2 (Table 7), except for 8 am where PET $\left(19.9^{\circ} \mathrm{C}\right.$ ) was like Street $1\left(20.1^{\circ} \mathrm{C}\right)$, and Street $2\left(20^{\circ} \mathrm{C}\right)$. The results also showed a positive correlation between street orientation PET values and H/W. Indeed, Street 1 and Street 2 showed relative values of PET at the hottest hours of the day despite the difference in orientation (Street $1 \mathrm{NE} / \mathrm{SW}$, 
Street 2 E/W). However, the H/W at Street 2 (1.89) is lower than Street 1 (equivalent to 2), showing a good level of shade. In contrast, Street 3 has N/S orientation, with H/W equivalent to 0.29 , highlighting a deficient shade level.

\subsubsection{PET coefficient and scores}

The PET coefficient was derived from the questionnaire survey. There is a specific question about indicating the importance of thermal comfort for people during the walking experience in the questionnaire. To define an "acceptable thermal range" for PET in summer, TSVs were within the three major categories (Neutral, slightly warm, warm). We summarised PET values and scores from $8 \mathrm{am}$ to $8 \mathrm{pm}$ according to thermal comfort ranking in Tel Aviv with a Csa climate (Table 9). The PET is reaching its highest score (1) at 8 am, 10 am, and 8 $\mathrm{pm}$, denoting a neutral thermal sensation. The lowest score is 0.25 at $4 \mathrm{pm}$ on the three streets, showing a warm thermal perception. PET had the same score of 0.5 and 0.25 at noon and 6 pm on Streets 1 and 2. Versus a warm thermal perception, with a score of 0.25 simultaneously on Street 3 (See Fig 5).

Table 9 PET values and score results in the selected streets.

\begin{tabular}{ccccccc}
\hline Time & PET Street & Scores & PET Street2 & Scores & PET Street 3 & Scores \\
\hline 8:00 AM & 20.1 & 1 & 20 & 1 & 19.9 & 1 \\
10:00 AM & 25.2 & 1 & 25.6 & 1 & 26 & 1 \\
12:00 PM & 26.5 & 0.5 & 26.4 & 0.5 & 28.4 & 0.25 \\
2:00 PM & 29.4 & 0.25 & 29.5 & 0.25 & 27.3 & 0.5 \\
4:00 PM & 30.5 & 0.25 & 31 & 0.25 & 29.5 & 0.25 \\
6:00 PM & 27.5 & 0.5 & 26.6 & 0.5 & 28 & 0.25 \\
8:00 PM & 23.6 & 1 & 23.1 & 1 & 24.8 & 1 \\
\hline
\end{tabular}




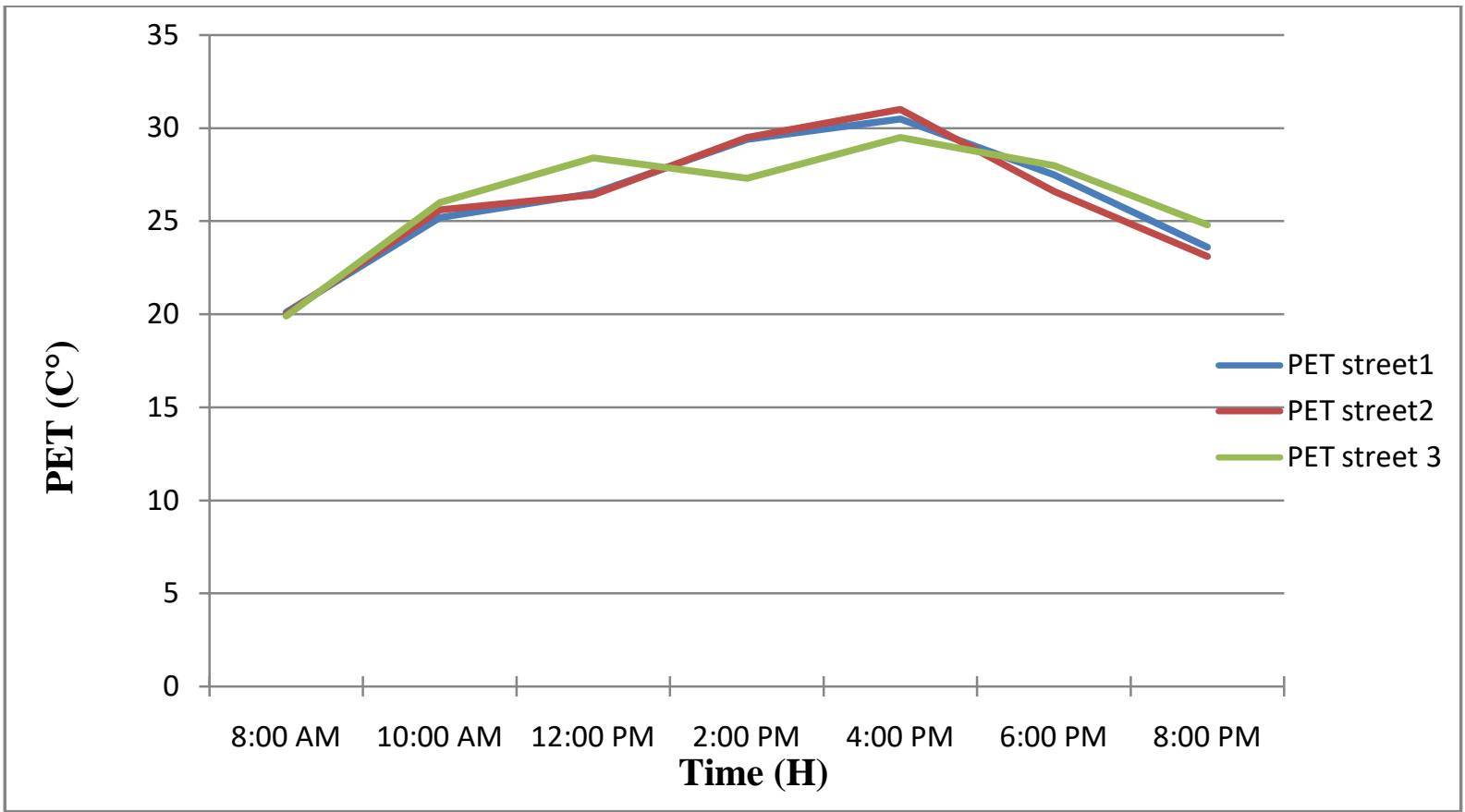

Fig. 5. Comparative analyses of PET results on three selected streets.

442 A straightforward analysis of the scores reveals that the same pedestrian facilities (e.g., social 443 space (café), slower traffic speed, and fewer traffic lanes) besides PET reached the maximum 444 scores of 1 at the three selected streets. However, the minimum values for the street facilities 445 (e.g., parks and spaces for playing, toilet, benches and seating area) were equivalent to 0, 446 while for the PET, the lowest score was 0.25 (See Fig 6). 


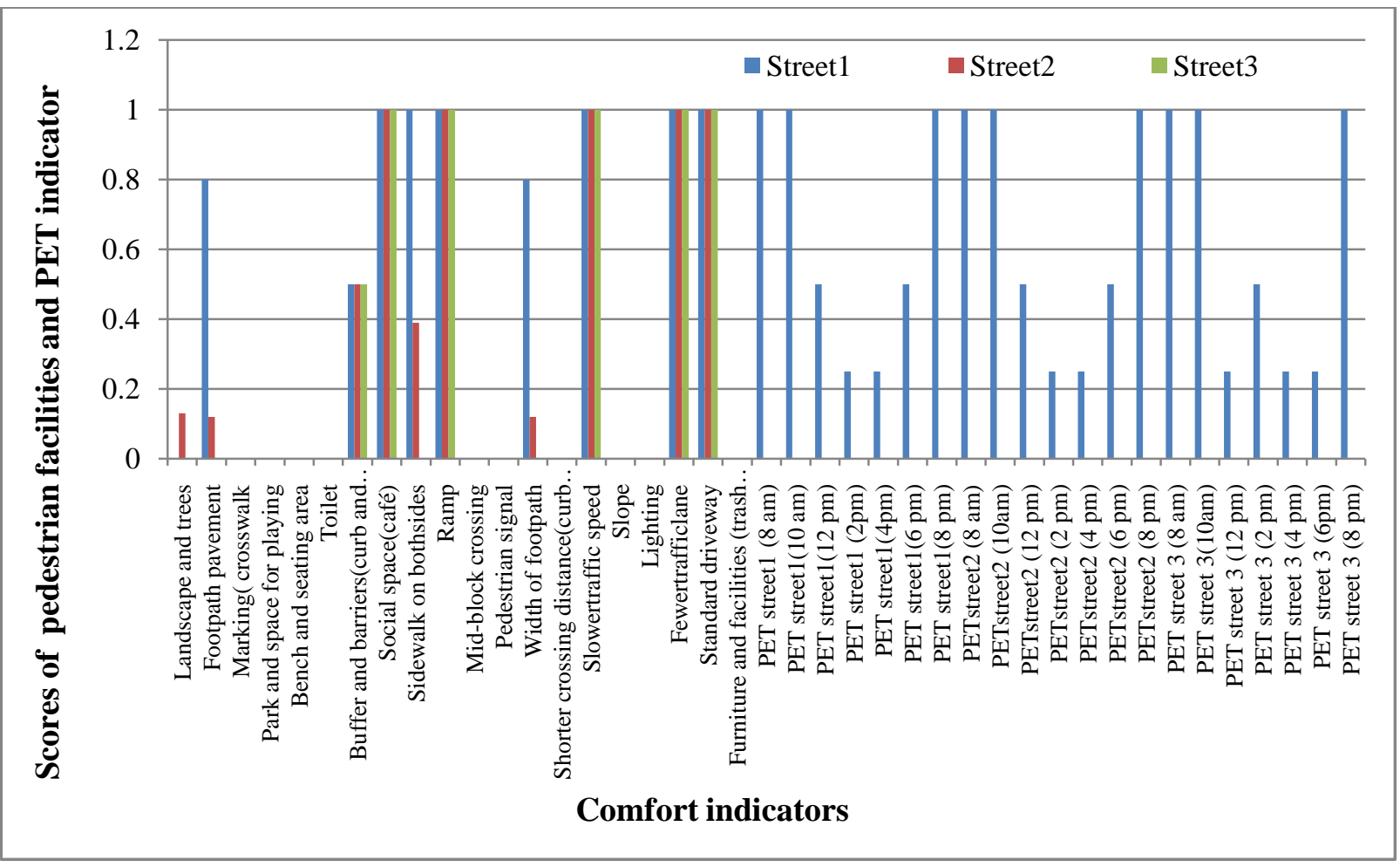

Fig. 6. Comparative analysis of comfort indicator scores on street level.

\subsection{Street Walkability Thermal Comfort Index (SWTC)}

The application of equation (1) allowed us to have the (SWTCI). The comparative analysis of SWTCI outcomes showed low-quality comfort walkability indicators specified by minimal pedestrian street design, which does not comply with international standards was included in the average of $23 \%-26 \%$, and finally, the lowest scores were at Street $3(20$ $\%<$ CWTCI $<23 \%$ ) (Fig 8). Most of the comfort walkability indicators are not existing. The selected streets are considered uncomfortable to use and unpleasant to walk (Table1). 
Table 10 SWTCI average and significance in the selected area.

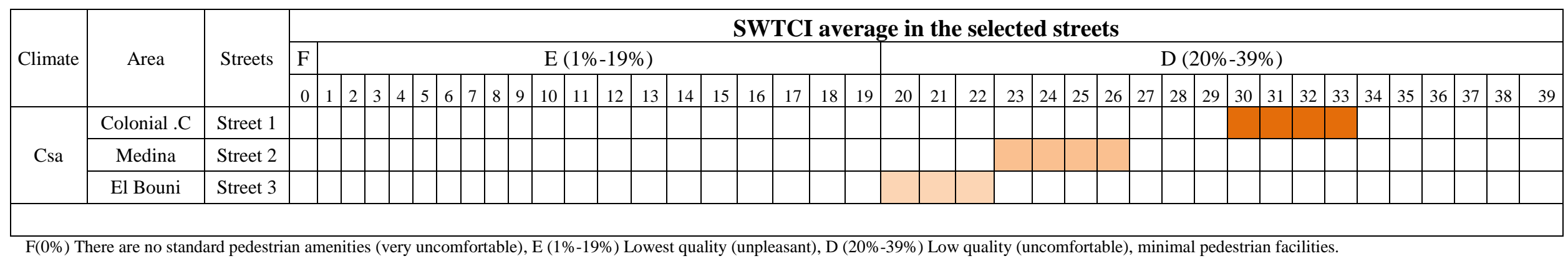


472 hours a day, $8 \mathrm{am}, 10 \mathrm{am}$, and $8 \mathrm{pm}$, when the thermal sensation is neutral with 32.90\%, $47326.28 \%$, and $23.28 \%$, respectively. However, SWTCI gets the minimum rating at 4 pm when 474 the thermal perception is warm, showing $29.86 \%, 23.24 \%$, and $20.23 \%$, respectively (Fig 8).

475

476

477

478

479

480

481

482

483

484

485

486

487

The corresponding SWTCI values at street 1 got $30.85 \%$ and $29.86 \%$ by increasing from noon to $4 \mathrm{pm}$. That is reflecting a slightly warm and warm thermal sensation, respectively. STCWI was rising from $6 \mathrm{pm}$ to 8 pm with $30.8 \%$ and $32.90 \%$ (Fig 7.a). The variation of STCWI was similar in the two streets (Colonial Center and Medina)(Fig7.a, b); however, the STCWI rating on Street 1 was higher than Street 2 (Fig 8).

Regarding Street 3 (El Bouni neighborhood), the results show a noticeable difference comparing to the previous STCWI rating. Three hours a day (12 am, $4 \mathrm{pm}$, and $6 \mathrm{pm}$ ) characterized by a warm thermal sensation get the lowest STCWI rating $(20.23 \%, 20.24 \%)$ respectively (Fig 7.c). However, STCWI ranking at Street 3 is inferior to both previous STCWI results (Fig 8). 


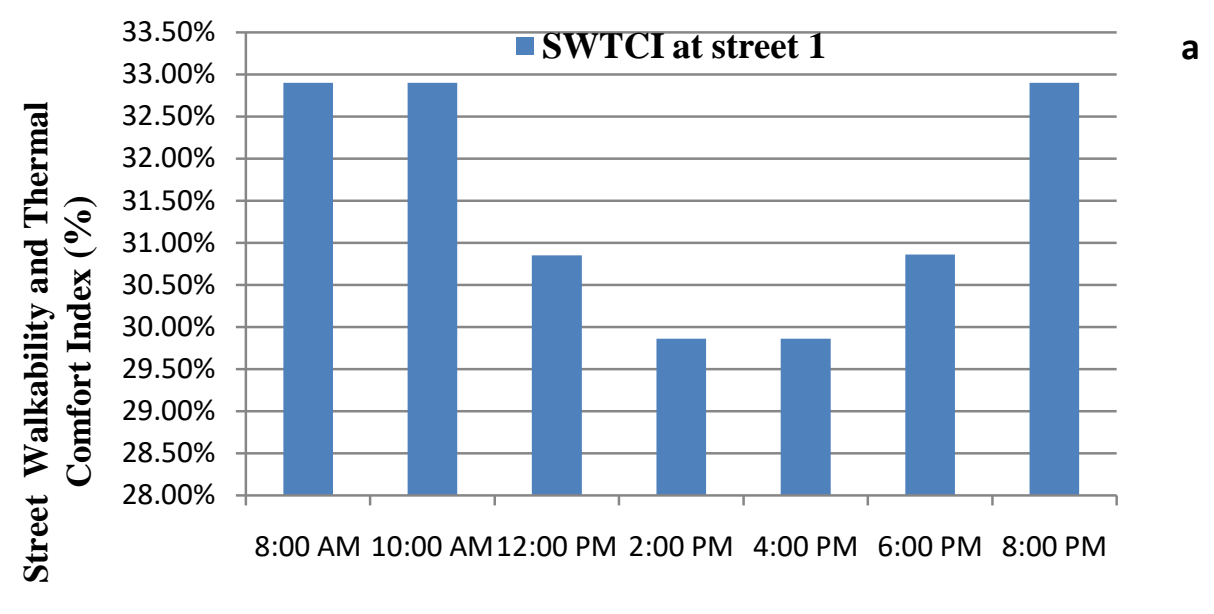

Time (H)
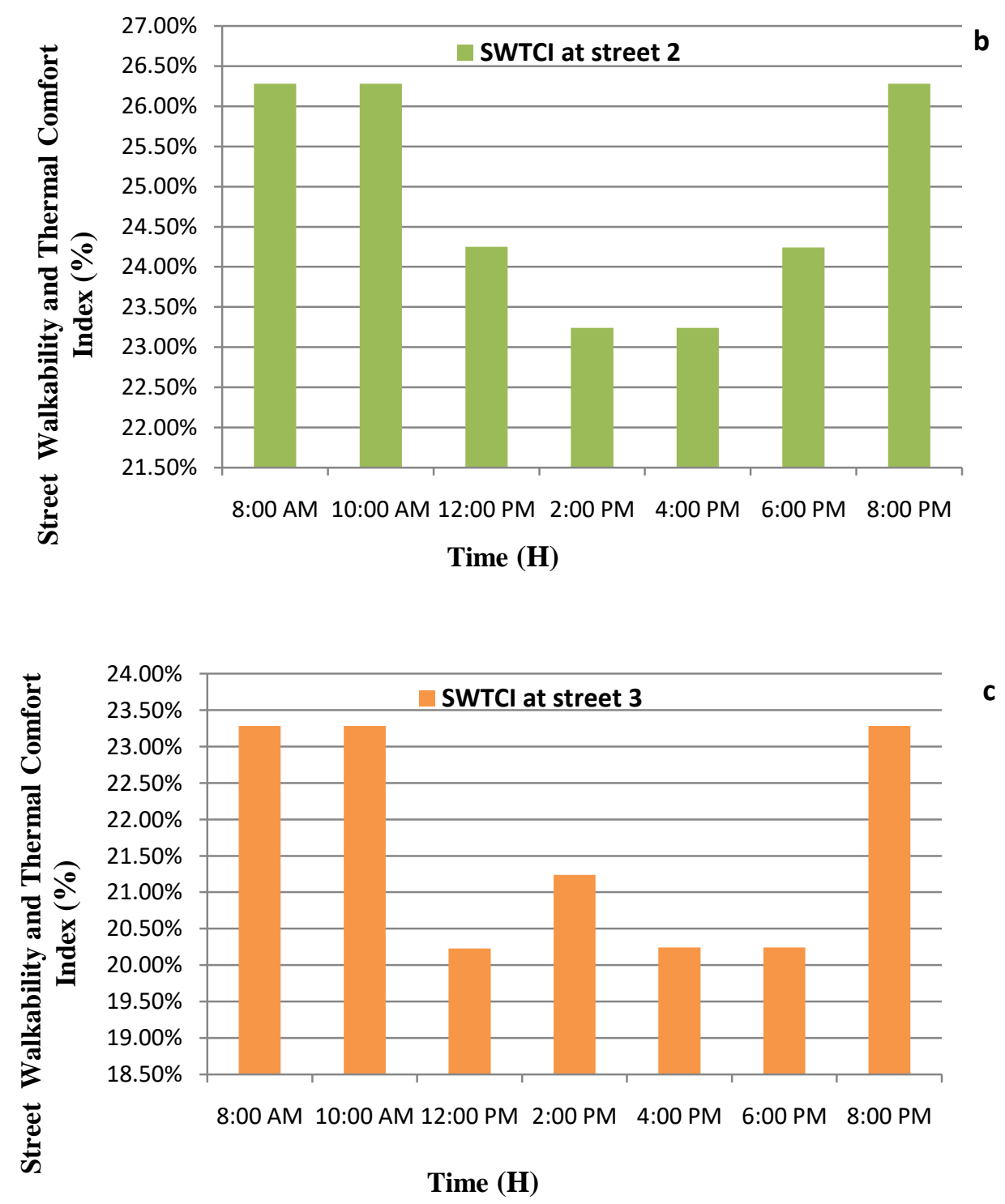

Street 1 in the Colonial center, Street 2 in Medievalneighborhood (Medina), Street 3 in El Bouni

Fig. 7.Street walkability Thermal Comfort Index at the selected streets 


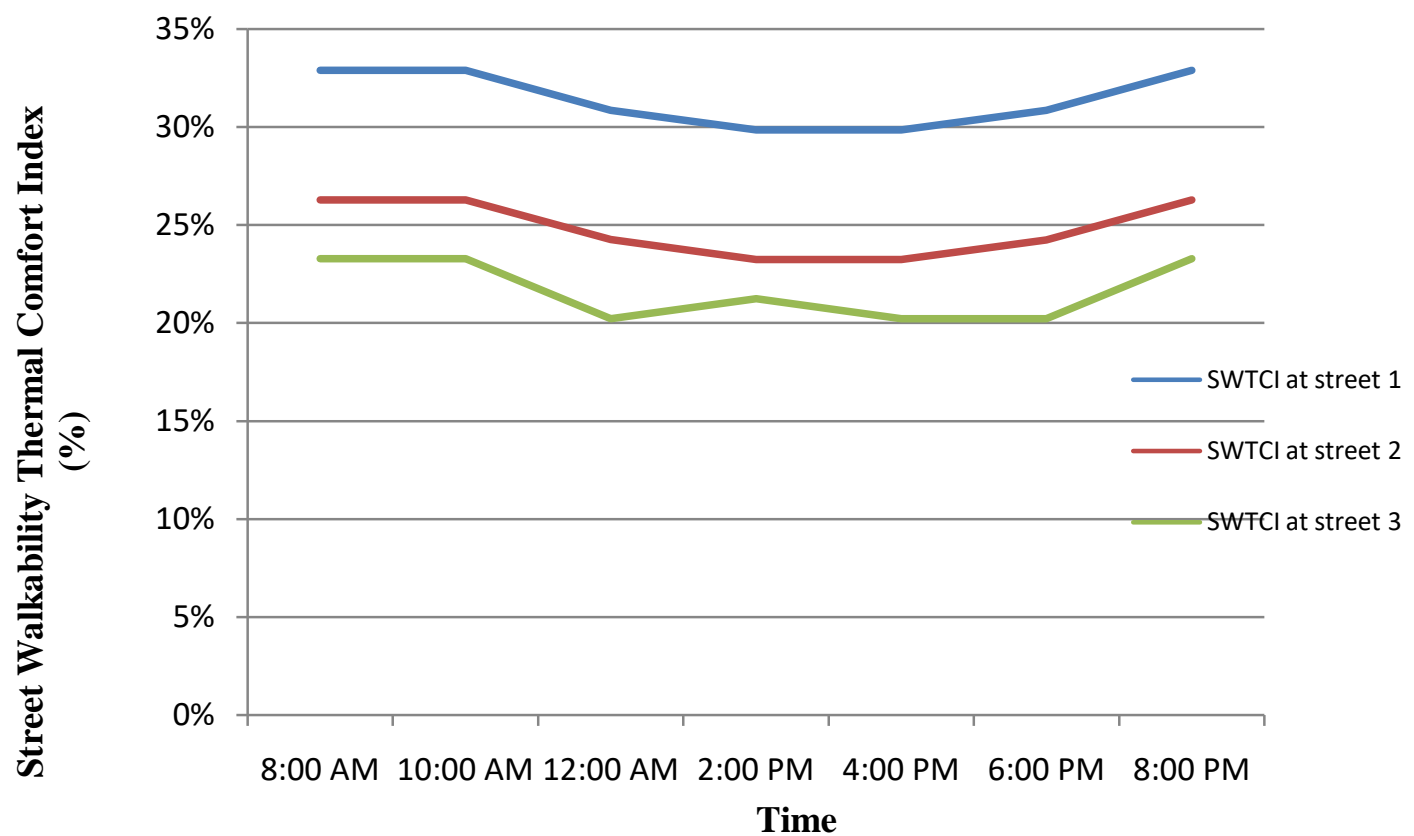

493

494

495

Fig. 8. Comparatives analysis of the Street Walkability Thermal Comfort Index on the selected streets

\section{Discussion}

To make the walking experience pleasant and more suitable, we need a pertinent rating system that can evaluate the existing pedestrian comfort environment and identify the problems that can be used for suggesting solutions. In this aim, the current research intended to examine 22 comfort walkability indicators on the sidewalk scale, using an innovative method including pedestrian comfort facilities and PET. The proposed model was tested in Annaba; Algeria. This model fulfilled the need for rating pedestrian comfort and enhancing walkability scores by combining street comfort design and thermal comfort.

\subsection{Impact of the pedestrian comfort facilities}

This study's findings showed the relevance of the selected indicators. Indeed, most themes are valued as very relevant for pedestrian comfort. Besides offering convenience, the requested factors included a potential sign of safety, attractiveness, and usability. For example, besides suitable signage and sufficient time for crossings, the speed limit provides 
comfort and safety (Lamour et al., 2019; Mateo-Babiano, 2016). Street lighting provides a pleasant and secure pedestrian setting at night (Loukaitou-Sideris, 2006). Also, the results reveal some other crucial comfort attributes such as a sidewalk on sides, foot pavement, the width of the footpath, benches, and seating area. Those define pedestrian convenience and ensure a pleasant walking experience (Aghaabbasi et al., 2018) for all categories, including children, older adults, and people with disabilities. Moreover, these indicators allowed enjoying the social life (Jacobs, 1993; Marcus and Francis, 1997). Slope, toilets, curb ramps are necessary for pedestrian comfort and ensure usability and accessibility (Asadi-Shekari et al., 2019).

\subsection{The PET effect on walking comfort}

The Envi-met model allows human thermal comfort simulation for the current and future climatic conditions estimated by regional climate models. The calibrated model was successfully validated based on the difference between measured and simulated air temperature, showing a good correlation between set data (Acero and Herranz-Pascual, 2015; Chen and Ng, 2013; Müller et al., 2014). This study also used the Rayman software to calculate the PET based on calibrated data to provide more accurate data of the existing thermal comfort model. For example, simulated $T_{a}$ and $T_{m r t}$ values agree much better with measurement data(Lee et al., 2016; Tan et al., 2016). Moreover, the results highlighted the $\mathrm{h} / \mathrm{w}$ ratio and orientation on thermal comfort conditions (Andreou, 2013). For example, Street 3 (h/w of 4) has higher air temperature, $\mathrm{T}_{\mathrm{mrt}}$ and PET values in comparison to Street $1 \mathrm{~h} / \mathrm{w}$ of 2) and Street $2(\mathrm{~h} / \mathrm{w}$ of 1.83$)$.

As introduced in Tables 4 and 5, the thermal sensation advised for the summer time in the Csa climate are neutral, slightly warm, and warm. Formerly PET ranking amid $19.9^{\circ} \mathrm{C}$ and $31^{\circ} \mathrm{C}$. The inquiry of results PET scores was fluctuating according to the time of day in 
summer. The PET results at the three selected streets showed the similarity of PET ratings in Street1 and Street 2 from 8 am to $4 \mathrm{pm}$. However, PET in Street 2 is lower than PET at Street 1 from $6 \mathrm{pm}$ to $8 \mathrm{pm}$. We noted that the thermal sensation in both streets (Streets 1 and 2) is almost the same (Table 9, Fig 6). Alternatively, PET at Street 3 is higher than the previous streets, which involve a warm sensation in three significant hours of the day (12 am, $4 \mathrm{pm} ; 6 \mathrm{pm})$ with a harmful effect on pedestrian comfort.

Those findings are strongly supported by $\mathrm{Wu}$ and Chen (2017), confirming the importance of the High-rise building on both sides of streets; their shades significantly impact the thermal near-surface surrounding environment. Indeed, the concrete pavement surface temperatures shaded by buildings were relatively $16{ }^{\circ} \mathrm{C}$ lower than those bared to solar radiation during mid-day in the summer. Besides being significantly crucial to citizens, trees provide shade, allowed walking during the hottest hours of the day. Indeed trees generate the cooling effect by reducing air temperature and $\mathrm{T}_{\mathrm{mrt}}$ (Bowler et al., 2010; Lee et al., 2016, 2013; Lee and Mayer, 2015; Mullaney et al., 2015). Moreover, the urban green cover can massively absorb high amounts of solar radiation (Shortwave and long-wave radiation) (Oke, 1982) and adding aesthetic value (Sousa et al., 2016).

\subsubsection{Interactivity of PET and pedestrian comfort facilities on SWTCI}

Among the many output possibilities derived from the SWTCI tool, we extracted those aiming to illustrate the PET assessment's usefulness.

The highest SWTCI at the three streets $(33 \%, 26 \%$, and 23\%) was correlated to neutral thermal sensation, reflecting the lowest amounts of PET followed by slightly warm. On the other hand, the lowest SWTCI rate in the selected streets $(30 \%, 23 \%$, and $20 \%)$ was related to the warm category of thermal sensation. In this optic, we can confirm the importance of PET in the assessment of the SWTCI process. Thermal comfort is considered a vital comfort 
walkability factor in improving pedestrian activity and a healthy environment, confirming the importance of the climatic conditions in outdoor urban spaces and the quality of life and wellbeing in cities(Cohen et al., 2013; Givoni, B et al., 2003).

Furthermore, the results recommended walking hours activity at 8 am,10 am, and 8 pm defined as thermally comfortable hours in summer with a neutral thermal sensation $(20<$ PET $<26)$, followed by 6 pm with a slightly warm thermal perception $(26.84<$ PET<27.5). However, the warm thermal sensation is not recommended for walking and made an uncomfortable condition $(28<\mathrm{PET}<31)$ at 12 am and $2 \mathrm{pm}$. Thus, the pedestrians walking in the shaded zone could improve thermal sensation (Lee et al., 2020). For example, the thermal sensation scale is expressed as slightly warm instead of warm for subtropical climates (Huang et al., 2017).

The proposed model can improve the pedestrian street comfort design by suggesting enhancing the indicators scores and comparing existing conditions with standards. Some pedestrian facilities such as landscape and trees and footpath pavement have a dual role; first, they improve the sidewalk's comfort conditions, and second; they increase pedestrians' thermal comfort. Landscape and trees are considered the principal component of attractiveness, safety, and usability on street level (Aghaabbasi et al., 2019, 2017).Adding vegetation can reduce mid-daytime heat by shading ground and evapotranspiration (Donovan and Butry, 2009; Gillner et al., 2015; Wu and Chen, 2017) and promoting walking hot hours of the day. Also, some paving materials such as cement tiles facilitate the accessibility of wheelchairs and stroller. The tiles with lighter pigmentation can absorb less heat and permit better thermal comfort (Synnefa et al., 2006).

Regarding the evaluated streets in this study, enhancing some pedestrian comfort facilities scores such as landscape and trees, benches and seating area, lighting, the width of 
the footpath, footpath materials can significantly improve the SWTCI rates. We can enhance the pedestrians' comfort by analyzing the existing variable's quality standards (See Table 7 and Appendices A and B and C). The comfort indicators could achieve the ideal score of 1 by performing current scores. Thus, applying the suggested improvements in Appendix C leads to a relevant upgrade to SWTCI3. Indeed, it increased from $23 \%$ to $38 \%$ but still included in the same category (D).

Although the SWTCI results correlate to the PET, improving other pedestrian comfort indicators can significantly affect the SWTCI. For example, for a street without a sidewalk, most of the scores will be zero regardless of PET. In addition, some pedestrian facilities, such as footpath pavement (pavement type material) as well as landscape and trees, could have a dual role in improving the walkability and thermal comfort scores. Furthermore, including additional parameters such as building material and color, besides analyzing the effect of adding vegetation and comparing the pavement material on thermal comfort, could be other interesting perspectives on the dual role factors for future research.

It is worthy to note the possibility of improving all the pedestrian comfort indicators by considering the standard guidelines (See Appendix A) and following the same method of Asadi-Shekari et al.(2019) (See Appendix B).Using the SWTCI method would help authorities improve comfort walkability conditions on the street level and enhance citizens' comfort potential. This design model can transform uncomfortable streets into pleasant and convenient environments within different street morphology and length. Indeed, the selected streets have fulfilled these requirements, proving the SWTCI high prospective and reliable applicability. 

PETas a comfort walkability indicator. This method is an innovative approach to combining pedestrian comfort facilities and thermal comfort on the street scale. The current process involved using a questionnaire survey, observations and in situ measurements. Using Envimet and Rayman allowed obtaining current PET besides identifying the thermal comfort range. Thus, the SWTCI met the recent walkability audit tool (PLOS) and the successful thermal comfort approaches. conditions for all street morphology. Moreover, it is helpful to evaluate the existing sidewalk condition by following an easy process assessment. Applying this model can improve the existing street features and transform the streets into ideal comfortable pedestrian environments. This promising initiative can be part of a sustainable development process and healthy living strategies. The SWTCI could be explored in the Mediterranean area and other climate zones. the fisheye technique to facilitate the quantitative interpretation of results, the absence of 623 some comfort indicators (e.g., drinking fountains, tactile pavements, elevators next to a sky624 bridge) considering their rareness in the selected area, besides the lack of building's characteristics (e.g., materials, colors). Thus, combining these factors in people's perceptions and analyzing the vegetation and footpath material effects on thermal comfort could be an

627 added value for the SWTCI. Moreover, improving the SWTCI tool for each type of street, 628 besides comparing different cities with different climates, could be an interesting topic for 
629 future research. In addition, further studies can use similar methodologies to develop user630 friendly software for the SWTCI estimation.

\section{Acknowledgements}

632

I wish to thank all of those who have supported my research for their helpful 633 comments during its accomplishment. In particular, I would like to acknowledge the Local 634 Environment Management and Analysis (LEMA) group at the University of Liege. The 635 funding for this project was made possible through a research grant obtained from the 636 Ministry of Higher Education and Scientific Research Algeria under the Programme National 637 Exceptional (PNE).

638

639

640

641

642

643

644

645

646

647

648

649 
651

652

653

654

655

656

657

658

659

660

661

662

663

664

665

666

667

668

669

670

671

672

673

674

675

676

677

678

679

680

681

682

683

684

685

686

687

688

689

690

691

692

693

694

695

696

697

698

Acero, J.A., Herranz-Pascual, K., 2015. A comparison of thermal comfort conditions in four urban spaces by means of measurements and modelling techniques. Building and Environment 93, 245-257. https://doi.org/10.1016/j.buildenv.2015.06.028

Aghaabbasi, M., Moeinaddini, M., Asadi-Shekari, Z., Shah, M.Z., 2019. The equitable use concept in sidewalk design. Cities 88, 181-190. https://doi.org/10.1016/j.cities.2018.10.010

Aghaabbasi, M., Moeinaddini, M., Zaly Shah, M., Asadi-Shekari, Z., 2017. A new assessment model to evaluate the microscale sidewalk design factors at the neighbourhood level. Journal of Transport \& Health 5, 97-112. https://doi.org/10.1016/j.jth.2016.08.012

Aghaabbasi, M., Moeinaddini, M., Zaly Shah, M., Asadi-Shekari, Z., Arjomand Kermani, M., 2018. Evaluating the capability of walkability audit tools for assessing sidewalks. Sustainable Cities and Society 37, 475-484. https://doi.org/10.1016/j.scs.2017.12.001

Ali-Toudert, F., Mayer, H., 2007. Thermal comfort in an east-west oriented street canyon in Freiburg (Germany) under hot summer conditions. Theor. Appl. Climatol. 87, 223237. https://doi.org/10.1007/s00704-005-0194-4

Ali-Toudert, F., Mayer, H., 2006. Numerical study on the effects of aspect ratio and orientation of an urban street canyon on outdoor thermal comfort in hot and dry climate. Building and Environment 41, 94-108. https://doi.org/10.1016/j.buildenv.2005.01.013

Andrade, H., Alcoforado, M.-J., Oliveira, S., 2011. Perception of temperature and wind by users of public outdoor spaces: relationships with weather parameters and personal characteristics. Int J Biometeorol 55, 665-680. https://doi.org/10.1007/s00484-0100379-0

Andreou, E., 2013. Thermal comfort in outdoor spaces and urban canyon microclimate. Renewable Energy 55, 182-188. https://doi.org/10.1016/j.renene.2012.12.040

Asadi-Shekari, Z., Moeinaddini, M., Aghaabbasi, M., Cools, M., Zaly Shah, M., 2019. Exploring effective micro-level items for evaluating inclusive walking facilities on urban streets (applied in Johor Bahru, Malaysia). Sustainable Cities and Society 49, 101563. https://doi.org/10.1016/j.scs.2019.101563

Asadi-Shekari, Z., Moeinaddini, M., Zaly Shah, M., 2015. Pedestrian safety index for evaluating street facilities in urban areas. Safety Science 74, 1-14. https://doi.org/10.1016/j.ssci.2014.11.014

Asadi-Shekari, Z., Moeinaddini, M., Zaly Shah, M., 2014. A pedestrian level of service method for evaluating and promoting walking facilities on campus streets. Land Use Policy 38, 175-193. https://doi.org/10.1016/j.landusepol.2013.11.007

Asadi-Shekari, Z., Moeinaddini, M., Zaly Shah, M., 2013a. Non-motorised Level of Service: Addressing Challenges in Pedestrian and Bicycle Level of Service. Transport Reviews 33, 166-194. https://doi.org/10.1080/01441647.2013.775613

Asadi-Shekari, Z., Moeinaddini, M., Zaly Shah, M., 2013b. Disabled Pedestrian Level of Service Method for Evaluating and Promoting Inclusive Walking Facilities on Urban Streets. J. Transp. Eng. 139, 181-192. https://doi.org/10.1061/(ASCE)TE.19435436.0000492

ASHRAE Standard, 2004. American Society of Heating, Refrigerating and Air-Conditioning Engineers 55.

Battista, G.A., Manaugh, K., 2018. Stores and mores: Toward socializing walkability. Journal of Transport Geography 67, 53-60. https://doi.org/10.1016/j.jtrangeo.2018.01.004

Boisseau, M.J., 1999. Sidewalk accessibility: A study of the continuing needs of pedestrians applied to the sidewalk planning and design process. 
Bowler, D.E., Buyung-Ali, L., Knight, T.M., Pullin, A.S., 2010. Urban greening to cool towns and cities: A systematic review of the empirical evidence. Landscape and Urban Planning 97, 147-155. https://doi.org/10.1016/j.landurbplan.2010.05.006

Bruse, M., Fleer, H., 1998. Simulating surface-plant-air interactions inside urban environments with a three dimensional numerical model. Environmental Modelling \& Software 13, 373-384. https://doi.org/10.1016/S1364-8152(98)00042-5

Cain, K.L., Millstein, R.A., Sallis, J.F., Conway, T.L., Gavand, K.A., Frank, L.D., Saelens, B.E., Geremia, C.M., Chapman, J., Adams, M.A., Glanz, K., King, A.C., 2014. Contribution of streetscape audits to explanation of physical activity in four age groups based on the Microscale Audit of Pedestrian Streetscapes (MAPS). Social Science \& Medicine 116, 82-92. https://doi.org/10.1016/j.socscimed.2014.06.042

Centre, E.C.-J.R., n.d. The Future of Cities [WWW Document]. European Commission. URL https://urban.jrc.ec.europa.eu/thefutureofcities/ (accessed 4.13.21).

Charalampopoulos, I., Tsiros, I., Chronopoulou-Sereli, A., Matzarakis, A., 2013. Analysis of thermal bioclimate in various urban configurations in Athens, Greece. Urban Ecosyst 16, 217-233. https://doi.org/10.1007/s11252-012-0252-5

Chen, L., Ng, E., 2013. Simulation of the effect of downtown greenery on thermal comfort in subtropical climate using PET index: a case study in Hong Kong. Architectural Science Review 56, 297-305. https://doi.org/10.1080/00038628.2012.684871

Christopoulou, P., Pitsiava-Latinopoulou, M., 2012. Development of a Model for the Estimation of Pedestrian Level of Service in Greek Urban Areas. Procedia - Social and Behavioral Sciences 48, 1691-1701. https://doi.org/10.1016/j.sbspro.2012.06.1144

Clifton, K.J., Livi Smith, A.D., Rodriguez, D., 2007. The development and testing of an audit for the pedestrian environment. Landscape and Urban Planning 80, 95-110. https://doi.org/10.1016/j.landurbplan.2006.06.008

Cohen, P., Potchter, O., Matzarakis, A., 2013. Human thermal perception of Coastal Mediterranean outdoor urban environments. Applied Geography 37, 1-10. https://doi.org/10.1016/j.apgeog.2012.11.001

Crews, D.E., Zavotka, S., 2006. Aging, Disability, and Frailty: Implications for Universal Design. Journal of PHYSIOLOGICAL ANTHROPOLOGY 25, 113-118. https://doi.org/10.2114/jpa2.25.113

Diogenes, M.C., Lindau, L.A., 2010. Evaluation of Pedestrian Safety at Midblock Crossings, Porto Alegre, Brazil. Transportation Research Record 2193, 37-43. https://doi.org/10.3141/2193-05

Donovan, G.H., Butry, D.T., 2009. The value of shade: Estimating the effect of urban trees on summertime electricity use. Energy and Buildings 41, 662-668. https://doi.org/10.1016/j.enbuild.2009.01.002

Ellen Vanderslice, O. of T., 1998. The Portland Pedestrian Design Guide.

Elnabawi, M.H., Hamza, N., Dudek, S., 2016. Thermal perception of outdoor urban spaces in the hot arid region of Cairo, Egypt. Sustainable Cities and Society 22, 136-145. https://doi.org/10.1016/j.scs.2016.02.005

Elnabawi, M.H., Hamza, N., Dudek, S., 2013. Use and evaluation of the ENVI-met model for two different urban forms in Cairo, Egypt: measurements and model simulations. Presented at the 13th Conference of International Building Performance Simulation Association, Chambéry, France.

Fruin, J.J., 1971. Pedestrian planning and design.

Galanis, A., Eliou, N., 2011. Evaluation of the pedestrian infrastructure using walkability indicators. WSEAS Transactions on Environment and Development 7, 385-394.

Gehl, J., Kaefer, L.J., Reigstad, S., 2006. Close encounters with buildings. Urban Des Int 11, 29-47. https://doi.org/10.1057/palgrave.udi.9000162 
Gillner, S., Vogt, J., Tharang, A., Dettmann, S., Roloff, A., 2015. Role of street trees in mitigating effects of heat and drought at highly sealed urban sites. Landscape and Urban Planning 143, 33-42. https://doi.org/10.1016/j.landurbplan.2015.06.005

Givoni, B, Noguchi, M., Saaroni, H., Pochter, O., Yaacov, Y, Feller, N, 2003. Outdoor comfort research issues. Energy and Buildings 1, 77-86.

Gulyás, Á., Unger, J., Matzarakis, A., 2006. Assessment of the microclimatic and human comfort conditions in a complex urban environment: Modelling and measurements. Building and Environment 41, 1713-1722. https://doi.org/10.1016/j.buildenv.2005.07.001

Gunn, L.D., King, T.L., Mavoa, S., Lamb, K.E., Giles-Corti, B., Kavanagh, A., 2017. Identifying destination distances that support walking trips in local neighborhoods. Journal of Transport \& Health 5, 133-141. https://doi.org/10.1016/j.jth.2016.08.009

Huang, T., Li, J., Xie, Y., Niu, J., Mak, C.M., 2017. Simultaneous environmental parameter monitoring and human subject survey regarding outdoor thermal comfort and its modelling. BUILD \& ENVIRON. 125, 502-514. https://doi.org/10.1016/j.buildenv.2017.09.015

Jacobs, A.B., 1993. Great streets. ACCESS Magazine 1, $23-27$.

Jaskiewicz, F., 2000. PEDESTRIAN LEVEL OF SERVICE BASED ON TRIP QUALITY, in: Transportation Research Circular. Presented at the Urban Street SymposiumTransportation Research Board; American Association of State Highway and Transportation Officials; American Society of Civil Engineers; Federal Highway Administration; Institute of Transportation Engineers; and National Association of County Engineers.

Jendritzky, G, de Dear, R, Havenith, G, 2012. UTCI why another thermal index? International Journal of Biometeorology 3, 421-428.

Jensen, S.U., 2007. Pedestrian and Bicyclist Level of Service on Roadway Segments. Transportation Research Record 2031, 43-51. https://doi.org/10.3141/2031-06

Johansson, E., Thorsson, S., Emmanuel, R., Krüger, E., 2014. Instruments and methods in outdoor thermal comfort studies - The need for standardization. Urban Climate 10, 346-366. https://doi.org/10.1016/j.uclim.2013.12.002

Johnson, R.S., 2005. Pedestrian Safety Impacts of Curb Extensions: A Case Study.

Kang, L., Xiong, Y., Mannering, F.L., 2013. Statistical analysis of pedestrian perceptions of sidewalk level of service in the presence of bicycles. Transportation Research Part A: Policy and Practice 53, 10-21. https://doi.org/10.1016/j.tra.2013.05.002

Kántor, N., Égerházi, L., Unger, J., 2012. Subjective estimation of thermal environment in recreational urban spaces - Part 1: investigations in Szeged, Hungary. Int J Biometeorol 56, 1075-1088. https://doi.org/10.1007/s00484-012-0523-0

Kelly, C.E., Tight, M.R., Hodgson, F.C., Page, M.W., 2011. A comparison of three methods for assessing the walkability of the pedestrian environment. Journal of Transport Geography 19, 1500-1508. https://doi.org/10.1016/j.jtrangeo.2010.08.001

Kihl, M., Brennan, D., Gabhawala, N., List, J., Mittal, P., 2005. Livable communities: An evaluation guide. Washington, DC: AARP Public Policy Institute.

Kim, S., Park, S., Lee, J.S., 2014. Meso- or micro-scale? Environmental factors influencing pedestrian satisfaction. Transportation Research Part D: Transport and Environment 30, 10-20. https://doi.org/10.1016/j.trd.2014.05.005

King, M.J., Soole, D., Ghafourian, A., 2009. Illegal pedestrian crossing at signalised intersections: Incidence and relative risk. Accident Analysis \& Prevention 41, 485490. https://doi.org/10.1016/j.aap.2009.01.008

Klemm, W., Heusinkveld, B.G., Lenzholzer, S., Jacobs, M.H., Van Hove, B., 2015. Psychological and physical impact of urban green spaces on outdoor thermal comfort 
during summertime in The Netherlands. Building and Environment 83, 120-128. https://doi.org/10.1016/j.buildenv.2014.05.013

Knez, I., Thorsson, S., 2006. Influences of culture and environmental attitude on thermal, emotional and perceptual evaluations of a public square. Int J Biometeorol 50, 258268. https://doi.org/10.1007/s00484-006-0024-0

Koh, P.P., Wong, Y.D., 2013. Comparing pedestrians' needs and behaviours in different land use environments. Journal of Transport Geography 26, 43-50. https://doi.org/10.1016/j.jtrangeo.2012.08.012

Köppen, W., 2020. Die klimate der erde: Grundriss der klimakunde. Walter de Gruyter GmbH \& Co KG.

Labdaoui, K., Mazouz, S., Acidi, A., Cools, M., Moeinaddini, M., Teller, J., 2021. Utilizing thermal comfort and walking facilities to propose a comfort walkability index (CWI) at the neighbourhood level. Building and Environment 193, 107627. https://doi.org/10.1016/j.buildenv.2021.107627

Lai, D., Guo, D., Hou, Y., Lin, C., Chen, Q., 2014. Studies of outdoor thermal comfort in northern China. Building and Environment 77, 110-118. https://doi.org/10.1016/j.buildenv.2014.03.026

Lamour, Q., Morelli, A.M., Marins, K.R. de C., 2019. Improving walkability in a TOD context: Spatial strategies that enhance walking in the Belém neighbourhood, in São Paulo, Brazil. Case Studies on Transport Policy 7, 280-292. https://doi.org/10.1016/j.cstp.2019.03.005

Landis, B.W., Vattikuti, V.R., Ottenberg, R.M., McLeod, D.S., Guttenplan, M., 2001. Modeling the Roadside Walking Environment: Pedestrian Level of Service. Transportation Research Record 1773, 82-88. https://doi.org/10.3141/1773-10

Lee, H., Holst, J., Mayer, H., 2013. Modification of Human-Biometeorologically Significant Radiant Flux Densities by Shading as Local Method to Mitigate Heat Stress in Summer within Urban Street Canyons. Advances in Meteorology 2013, 1-13. https://doi.org/10.1155/2013/312572

Lee, H., Mayer, H., 2015. Green coverage changes within an ESE-WNW street canyon as a planning measure to maintain human thermal comfort on a heat wave day.

Lee, H., Mayer, H., Chen, L., 2016. Contribution of trees and grasslands to the mitigation of human heat stress in a residential district of Freiburg, Southwest Germany. Landscape and Urban Planning 148, 37-50. https://doi.org/10.1016/j.landurbplan.2015.12.004

Lee, Kim, 2019. Shared Space and Pedestrian Safety: Empirical Evidence from Pedestrian Priority Street Projects in Seoul, Korea. Sustainability 11, 4645. https://doi.org/10.3390/su11174645

Lee, L.S.H., Cheung, P.K., Fung, C.K.W., Jim, C.Y., 2020. Improving street walkability: Biometeorological assessment of artificial-partial shade structures in summer sunny conditions. Int J Biometeorol 64, 547-560. https://doi.org/10.1007/s00484-019-018409

Lin, T.-P., Matzarakis, A., 2008. Tourism climate and thermal comfort in Sun Moon Lake, Taiwan. Int J Biometeorol 52, 281-290. https://doi.org/10.1007/s00484-007-0122-7

Lin, T.-P., Tsai, K.-T., Liao, C.-C., Huang, Y.-C., 2013. Effects of thermal comfort and adaptation on park attendance regarding different shading levels and activity types. Building and Environment 59, 599-611. https://doi.org/10.1016/j.buildenv.2012.10.005

Liu, W., Zhang, Y., Deng, Q., 2016. The effects of urban microclimate on outdoor thermal sensation and neutral temperature in hot-summer and cold-winter climate. Energy and Buildings 128, 190-197. https://doi.org/10.1016/j.enbuild.2016.06.086 
Lobaccaro, G., Acero, J.A., 2015. Comparative analysis of green actions to improve outdoor thermal comfort inside typical urban street canyons. Urban Climate 14, 251-267. https://doi.org/10.1016/j.uclim.2015.10.002

Loukaitou-Sideris, A., 2006. Is it Safe to Walk?1 Neighborhood Safety and Security Considerations and Their Effects on Walking. Journal of Planning Literature 20, 219 232. https://doi.org/10.1177/0885412205282770

Manual, H.C., 2000. Highway capacity manual. Washington, DC 2, 1.

Marcus, C.C., Francis, C., 1997. People places: design guidlines for urban open space. John Wiley \& Sons.

Mateo-Babiano, I., 2016. Pedestrian's needs matter: Examining Manila's walking environment. Transport Policy 45, 107-115. https://doi.org/10.1016/j.tranpol.2015.09.008

Matzarakis, A., Mayer, H., Iziomon, M.G., 1999. Applications of a universal thermal index: physiological equivalent temperature. International Journal of Biometeorology 43, 7684. https://doi.org/10.1007/s004840050119

Matzarakis, A., Rutz, F., Mayer, H., 2010. Modelling radiation fluxes in simple and complex environments: basics of the RayMan model. Int J Biometeorol 54, 131-139. https://doi.org/10.1007/s00484-009-0261-0

Matzarakis, A., Rutz, F., Mayer, H., 2007. Modelling radiation fluxes in simple and complex environments - application of the RayMan model. Int J Biometeorol 51, 323-334. https://doi.org/10.1007/s00484-006-0061-8

Mayer, H., 1993. Urban bioclimatology. Experientia 49, 957-963. https://doi.org/10.1007/BF02125642

Mayer, H., Höppe, P., 1987. Thermal comfort of man in different urban environments. Theor Appl Climatol 38, 43-49. https://doi.org/10.1007/BF00866252

Miller, J.S., Bigelow, J.A., Garber, N.J., 2000. Calibrating Pedestrian Level-of-Service Metrics with 3-D Visualization. Transportation Research Record 1705, 9-15. https://doi.org/10.3141/1705-02

Moeinaddini, M., Asadi-Shekari, Z., Ismail, C.R., Zaly Shah, M., 2013. A practical method for evaluating parking area level of service. Land Use Policy 33, 1-10. https://doi.org/10.1016/j.landusepol.2012.11.014

Moeinaddini, M., Asadi-Shekari, Z., Zaly Shah, M., 2015. An urban mobility index for evaluating and reducing private motorized trips. Measurement 63, 30-40. https://doi.org/10.1016/j.measurement.2014.11.026

Morakinyo, T.E., Kong, L., Lau, K.K.-L., Yuan, C., Ng, E., 2017. A study on the impact of shadow-cast and tree species on in-canyon and neighborhood's thermal comfort. Building and Environment 115, 1-17. https://doi.org/10.1016/j.buildenv.2017.01.005

Moura, F., Cambra, P., Gonçalves, A.B., 2017. Measuring walkability for distinct pedestrian groups with a participatory assessment method: A case study in Lisbon. Landscape and Urban Planning 157, 282-296. https://doi.org/10.1016/j.landurbplan.2016.07.002

Mullaney, J., Lucke, T., Trueman, S.J., 2015. A review of benefits and challenges in growing street trees in paved urban environments. Landscape and Urban Planning 134, 157166. https://doi.org/10.1016/j.landurbplan.2014.10.013

Müller, N., Kuttler, W., Barlag, A.-B., 2014. Counteracting urban climate change: adaptation measures and their effect on thermal comfort. Theor Appl Climatol 115, 243-257. https://doi.org/10.1007/s00704-013-0890-4

Nikolopoulou, M., Baker, N., Steemers, K., 2001. Thermal comfort in outdoor urban spaces: understanding the human parameter. Solar Energy 70, 227-235. https://doi.org/10.1016/S0038-092X(00)00093-1 
Nikolopoulou, M., Lykoudis, S., 2006. Thermal comfort in outdoor urban spaces: Analysis across different European countries. Building and Environment 41, 1455-1470. https://doi.org/10.1016/j.buildenv.2005.05.031

Nilles, M., Kaparias, I., 2018. Investigating the relation of highway design standards with network-level walkability: The case study of Luxembourg. International Journal of Transportation Science and Technology 7, 254-263. https://doi.org/10.1016/j.ijtst.2018.08.001

Oke, T.R., 1982. The energetic basis of the urban heat island. Q.J Royal Met. Soc. 108, 1-24. https://doi.org/10.1002/qj.49710845502

Potchter, O., Cohen, P., Lin, T.-P., Matzarakis, A., 2018. Outdoor human thermal perception in various climates: A comprehensive review of approaches, methods and quantification. Science of The Total Environment 631-632, 390-406. https://doi.org/10.1016/j.scitotenv.2018.02.276

Retting, R.A., Ferguson, S.A., McCartt, A.T., 2003. A Review of Evidence-Based Traffic Engineering Measures Designed to Reduce Pedestrian-Motor Vehicle Crashes. Am J Public Health 93, 1456-1463.

Rodríguez, D.A., Aytur, S., Forsyth, A., Oakes, J.M., Clifton, K.J., 2008. Relation of modifiable neighborhood attributes to walking. Preventive Medicine 47, $260-264$. https://doi.org/10.1016/j.ypmed.2008.02.028

Ruiz-Padillo, A., Pasqual, F.M., Larranaga Uriarte, A.M., Cybis, H.B.B., 2018. Application of multi-criteria decision analysis methods for assessing walkability: A case study in Porto Alegre, Brazil. Transportation Research Part D: Transport and Environment 63, 855-871. https://doi.org/10.1016/j.trd.2018.07.016

Sahani, R., Bhuyan, P.K., 2014. PEDESTRIAN LEVEL OF SERVICE CRITERIA FOR URBAN OFF-STREET FACILITIES IN MID-SIZED CITIES. Transport 32, 221232. https://doi.org/10.3846/16484142.2014.944210

Salata, F., Golasi, I., de Lieto Vollaro, R., de Lieto Vollaro, A., 2016. Outdoor thermal comfort in the Mediterranean area. A transversal study in Rome, Italy. Building and Environment 96, 46-61. https://doi.org/10.1016/j.buildenv.2015.11.023

Sarkar S., 1993. DETERMINATION OF SERVICE LEVELS FOR PEDESTRIANS, WITH EUROPEAN EXAMPLES.

Sousa, M., Montalto, F., Palmer, M., 2016. Potential climate change impacts on green infrastructure vegetation. Urban Forestry \& Urban Greening 20. https://doi.org/10.1016/j.ufug.2016.08.014

Southworth, M., 2005. Designing the Walkable City. J. Urban Plann. Dev. 131, 246-257. https://doi.org/10.1061/(ASCE)0733-9488(2005)131:4(246)

Synnefa, A., Santamouris, M., Livada, I., 2006. A study of the thermal performance of reflective coatings for the urban environment. Solar Energy 80, 968-981. https://doi.org/10.1016/j.solener.2005.08.005

Taleai, M., Taheri Amiri, E., 2017. Spatial multi-criteria and multi-scale evaluation of walkability potential at street segment level: A case study of tehran. Sustainable Cities and Society 31, 37-50. https://doi.org/10.1016/j.scs.2017.02.011

Taleghani, M., Berardi, U., 2018. The effect of pavement characteristics on pedestrians' thermal comfort in Toronto. Urban Climate 24, 449-459. https://doi.org/10.1016/j.uclim.2017.05.007

Tan, D., Wang, W., Lu, J., Bian, Y., 2007. Research on Methods of Assessing Pedestrian Level of Service for Sidewalk. Journal of Transportation Systems Engineering and Information Technology 7, 74-79. https://doi.org/10.1016/S1570-6672(07)60041-5 
Tan, Z., Lau, K.K.-L., Ng, E., 2016. Urban tree design approaches for mitigating daytime urban heat island effects in a high-density urban environment. Energy and Buildings 114, 265-274. https://doi.org/10.1016/j.enbuild.2015.06.031

Thorsson, S., Honjo, T., Lindberg, F., Eliasson, I., Lim, E.-M., 2007. Thermal Comfort and Outdoor Activity in Japanese Urban Public Places. Environment and Behavior 39, 660-684. https://doi.org/10.1177/0013916506294937

Todorova, A., Asakawa, S., Aikoh, T., 2004. Preferences for and attitudes towards street flowers and trees in Sapporo, Japan. Landscape and Urban Planning 69, 403-416. https://doi.org/10.1016/j.landurbplan.2003.11.001

Troped, P.J., Cromley, E.K., Fragala, M.S., Melly, S.J., Hasbrouck, H.H., Gortmaker, S.L., Brownson, R.C., 2006. Development and Reliability and Validity Testing of an Audit Tool for Trail/Path Characteristics: The Path Environment Audit Tool (PEAT). Journal of Physical Activity and Health 3, S158-S175. https://doi.org/10.1123/jpah.3.s1.s158

Tseliou, A., Tsiros, I.X., Lykoudis, S., Nikolopoulou, M., 2010. An evaluation of three biometeorological indices for human thermal comfort in urban outdoor areas under real climatic conditions. Building and Environment 45, 1346-1352. https://doi.org/10.1016/j.buildenv.2009.11.009

VDI, V., 1998. 3787, Part I: Environmental Meteorology, Methods for the Human Biometeorological Evaluation of Climate and Air Quality for the Urban and Regional Planning at Regional Level. Part I: Climate. Part I: Climate. Beuth, Berlin.

Watanabe, S., Nagano, K., Ishii, J., Horikoshi, T., 2014. Evaluation of outdoor thermal comfort in sunlight, building shade, and pergola shade during summer in a humid subtropical region. Building and Environment 82, 556-565. https://doi.org/10.1016/j.buildenv.2014.10.002

$\mathrm{Wu}, \mathrm{Z}$., Chen, L., 2017. Optimizing the spatial arrangement of trees in residential neighborhoods for better cooling effects: Integrating modeling with in-situ measurements. Landscape and Urban Planning 167, 463-472. https://doi.org/10.1016/j.landurbplan.2017.07.015 


\begin{tabular}{|c|c|}
\hline Pedestrian comfort facilities & Standards \\
\hline Slower traffic speed & $30 \mathrm{~km} / \mathrm{H}$ based on the street standard. \\
\hline Buffer and barriers (curb and furnishing zone) & $\begin{array}{l}\checkmark \quad \begin{array}{l}\text { Curb standard: the lowest width of curb is equal to } 0.15 \mathrm{~m} \text {, } \\
\text { the minimal high is equivalent to } 0.10-0.15 \mathrm{~m}\end{array} \\
\checkmark \quad \text { Furnishing zone: the lowest acceptable width is } 1.2 \mathrm{~m} \text {; } \\
\text { however, the Interval }(1.8 \mathrm{~m}-2.4 \mathrm{~m}) \text { is recommended. }\end{array}$ \\
\hline Fewer traffic lanes, & $\checkmark \quad$ Standard 2 lanes. \\
\hline Mid-block crossing & $\begin{array}{l}\text { 1. Crosswalk number is changing, but not farther apart 60- } \\
90 \mathrm{~m} \text {, besides not contiguous than } 45 \mathrm{~m} \text { and does not ban } \\
\text { crossing further than } 120 \mathrm{~m} \text {. } \\
\text { 2. The representative width of the mid-block crossing is } 3 \\
\text { m. However, if the sidewalk is more extended than } 3.7 \mathrm{~m} \text {, } \\
\text { the crosswalk should be larger than the width. }\end{array}$ \\
\hline Landscape and trees & $\begin{array}{l}\quad \text { Trees Limb must have a clear vertical high of a minimum of } \\
2.4 \mathrm{~m}(1) \\
\checkmark \quad \text { Trees must be distant from intersections with a minimum of } \\
7.6 \mathrm{~m}(2) \\
\checkmark \quad \text { Trees interval must not exceed } 9 \text { m to ensure an extended } \\
\text { trees canopy. } \\
\checkmark \quad \text { Trees must be implanted on both sides of the sidewalk }\end{array}$ \\
\hline Furniture (trash receptacles) & $\begin{array}{l}\checkmark \quad \text { It must be in the furnishing zone within } 0.9 \text { m wide or more } \\
\text { extensive. } \\
\checkmark \quad \text { It must be far from the intersection with 9m of distance. } \\
\checkmark \quad \text { A distance of 0.6m, at least from the curb border, should be } \\
\text { respected. } \\
\checkmark \quad \text { One receptacle should be provided in each playground, } \\
\text { which has to be near benches. } \\
\checkmark \quad \text { It must have at least } 1.2 \mathrm{~m} \text { clear out concerning bus } \\
\text { facilities. } \\
\checkmark \quad \text { It must be placed every } 200-400 \mathrm{~m} .\end{array}$ \\
\hline Footpath pavement & $\begin{array}{l}\checkmark \quad \text { It must be solid, anti-slip, not rough, and extended. } \\
\checkmark \quad \text { The area of discontinuities should not be more than } 1.25 \\
\text { cm; besides, the thickness differences must be including } \\
\text { 0.6-1.25 }\end{array}$ \\
\hline Marking (crosswalk) & $\begin{array}{l}\text { The first type (Ladder or longitudinal) } \\
\checkmark \quad \text { The minimal width of a crosswalk is } 3 \mathrm{~m} \text {, but the suggested } \\
\quad \text { width is } 5 \mathrm{~m} \\
\checkmark \quad \text { The strips interval is } 0.3-1.5 \mathrm{~m} \\
\checkmark \quad \text { The width of the bands is between } 0.3-0.6 \mathrm{~m} \\
\text { The second type(Parallel or standard transverse) } \\
\checkmark \quad \text { The minimal crosswalk width is } 1.9 \mathrm{~m} \text {, but the suggested } \\
\quad \text { width is between } 3-4.5 \mathrm{~m} \\
\checkmark \quad \text { The width of the two bands is } 0.15-0.30 \mathrm{~m}\end{array}$ \\
\hline Sidewalk on bothsides & $\checkmark \quad$ Every side of the street must have a sidewalk. \\
\hline Width of footpath & $\begin{array}{l}\text { The footpath zone must be at least } 1.5 \mathrm{~m} \text {. However, the preferred } \\
\text { width is between } 1.8 \mathrm{~m}-2.4 \mathrm{~m}\end{array}$ \\
\hline Slope & The sidewalk slope $\leq 2 \%$ \\
\hline Lighting & 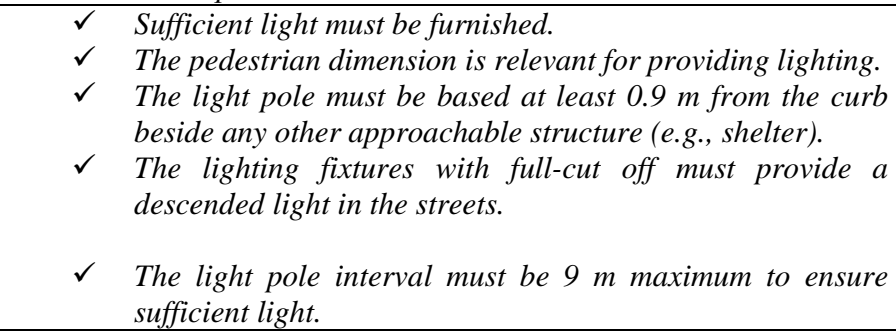 \\
\hline
\end{tabular}




\begin{tabular}{|c|c|}
\hline $\begin{array}{c}\text { Continued Pedestrian comfort } \\
\text { facilities }\end{array}$ & Standards \\
\hline Ramp & $\begin{array}{c}\text { A pedestrian surface characterised by a running slope superior to } 5 \% \\
\checkmark \quad \text { Maximal value of the slope is } 8.3 \% \\
\checkmark \quad \text { The minimal width is } 1.2 \mathrm{~m} \\
\checkmark \quad \text { An appropriate handrail must be furnished. }\end{array}$ \\
\hline Park and space for playing & $\begin{array}{l}\checkmark \quad \text { Parks and the public area must be effortlessly accessible on } \\
\text { foot or by bike for the user's categories (e.g., people with } \\
\text { different abilities besides children and alder). } \\
\checkmark \text { Parks and public spaces require to be safe, accessible, and } \\
\text { age-friendly. }\end{array}$ \\
\hline Social space (café) & $\checkmark \quad$ They should be located every $200-400 \mathrm{~m}$ \\
\hline Benches and seating area & $\begin{array}{l}\checkmark \quad \text { They must be provided in the frontage zone. } \\
\checkmark \quad \text { They must be implanted with a minimal distance of } 0.6 \mathrm{~m} \\
\text { from the curb. } \\
\checkmark \quad \text { They must be implanted with a minimal distance of } 9 \mathrm{~m} \text { from } \\
\text { the intersection. } \\
\checkmark \quad \text { They must be furnished at all bus stops. } \\
\checkmark \quad \text { They should be implanted every 200-400 m. } \\
\checkmark \quad \text { An area of } 1.2 \text { m should be given at the end of the seats to } \\
\text { allow strollers and wheelchairs station. } \\
\checkmark \quad \text { Every seat must be furnished with a minimal distance of } 0.6 \\
\text { m from the pedestrian traffic roads. } \\
\checkmark \text { A distance of } 1.5 \text { m should be respected between the seat } \\
\text { and any immobile furniture such as a drinking fountain, } \\
\text { trash receptacle or signpost. }\end{array}$ \\
\hline Toilet & $\begin{array}{l}\checkmark \quad \text { The public toilet must be implanted close to the bus stop } \\
\text { and at each Rapid Transit Station. Besides being adjoining } \\
\text { to parks and playing area. } \\
\checkmark \quad \text { Toilet interval implementation must be every } 500-800 \mathrm{~m} \text {. } \\
\checkmark \quad \text { For wheelchair users, a minimal distance of } 1.7 * 1.8 \mathrm{~m} \\
\text { should be respected. }\end{array}$ \\
\hline Pedestrian signal & 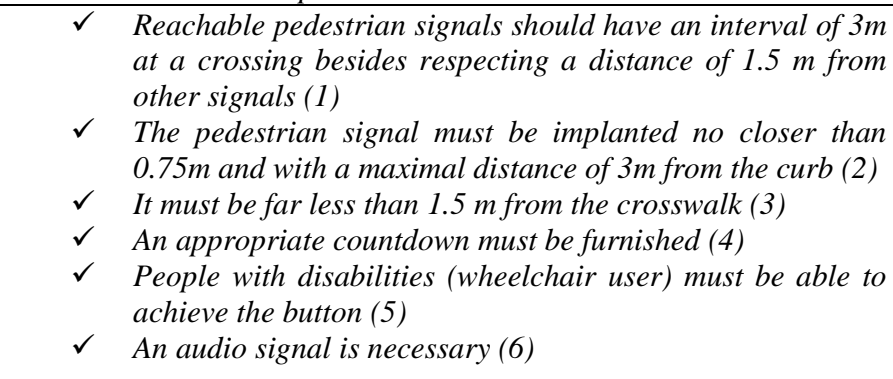 \\
\hline Shorter crossing distance(curb extension) & 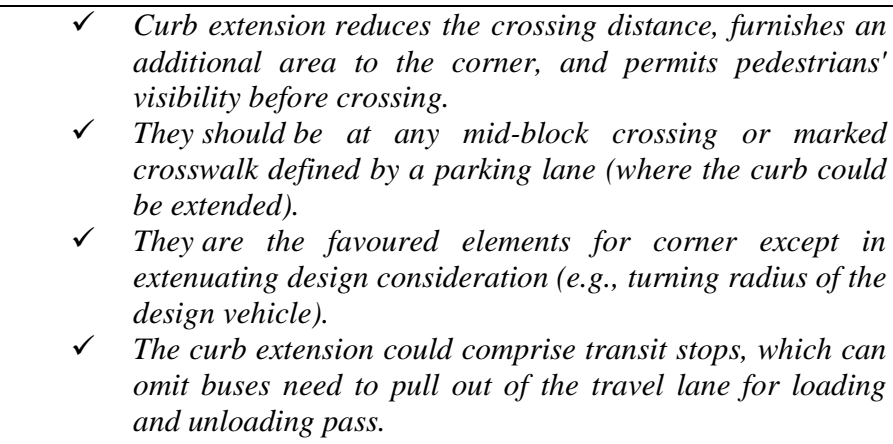 \\
\hline
\end{tabular}


Source Asadi-Shekari et al. ( 2019, 2015, 2014, 2013b)

\begin{tabular}{|c|c|}
\hline Facilities & scores \\
\hline Slower traffic speed & 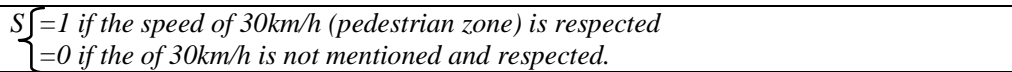 \\
\hline $\begin{array}{l}\text { Buffer and barriers (curb and } \\
\text { furnishing zone) }\end{array}$ & $\begin{array}{l}C=\text { Number of standard curb ramps } \\
N=\text { Total number of curb ramps the street needs } \\
P=C / N \\
\left\{\begin{array}{l}=1 \text { if } P \geq 1 \\
=P \text { if } P<1 \\
=0 \text { if the curbs are not required }\end{array}\right.\end{array}$ \\
\hline Fewer traffic lanes, & $\begin{array}{l}S\left\{\begin{array}{l}=0 \text { if } N^{\circ} \text { of lanes }>2 \\
\text { if } N^{\circ} \text { of lanes } \leq 2\end{array}\right.\end{array}$ \\
\hline Mid-block crossing & 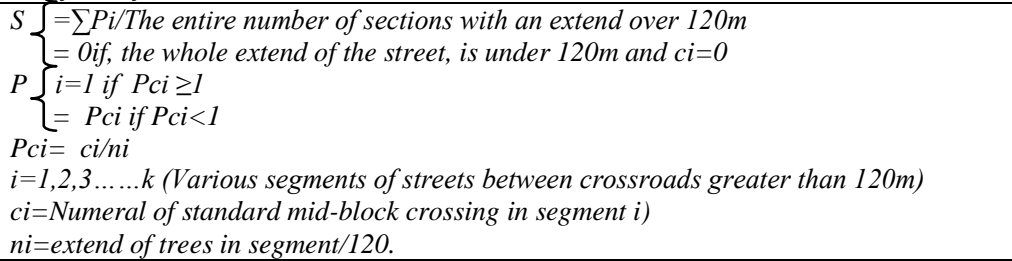 \\
\hline Landscape and trees & 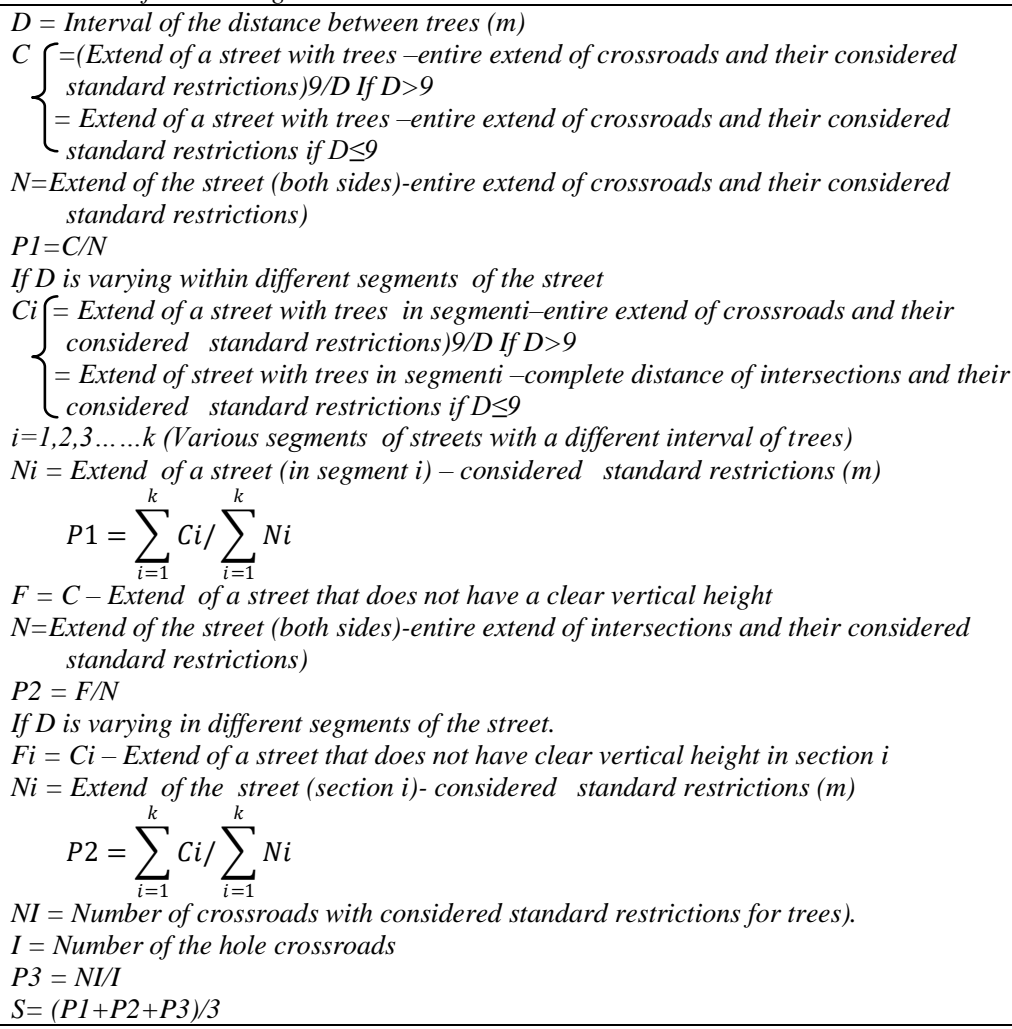 \\
\hline Furniture (trash receptacles) & $\begin{array}{l}C=\text { Extend of a street with guideline trash receptacle area }+ \text { their support distance }(\mathrm{m}) \\
N=\text { Extend of street }(\text { both sides })(\mathrm{m}) \\
S=C / N\end{array}$ \\
\hline Footpath pavement & 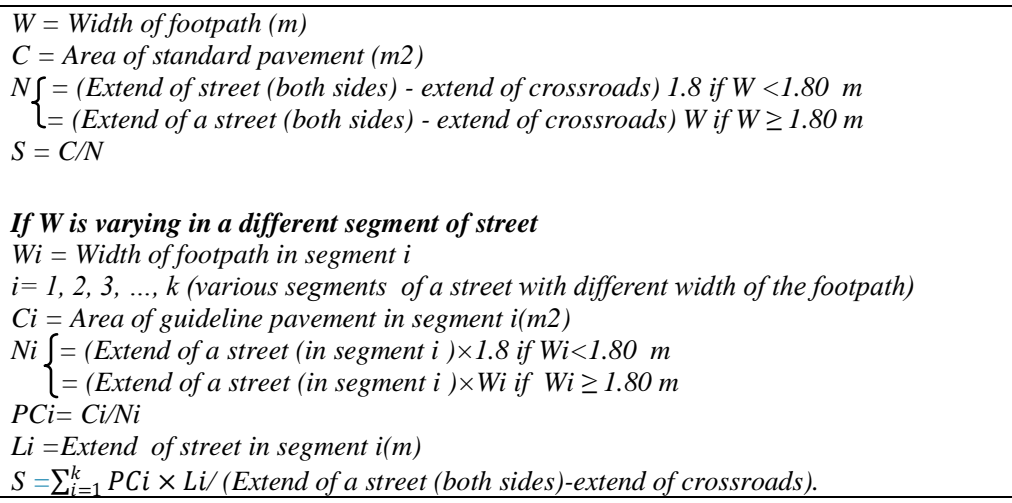 \\
\hline
\end{tabular}




\begin{tabular}{|c|c|}
\hline Continued Facilities & scores \\
\hline Marking (crosswalk) & 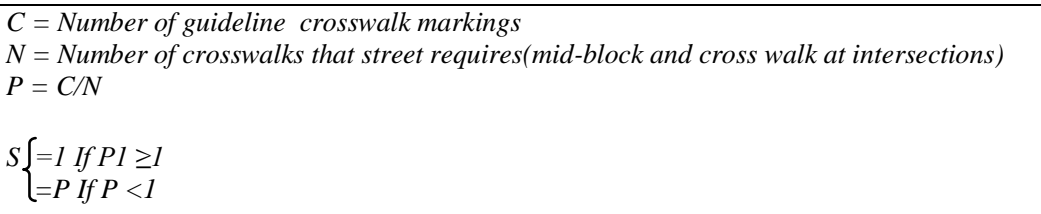 \\
\hline Sidewalk on bothsides & $\begin{array}{l}\begin{array}{l}a\left\{\begin{array}{l}=1 \text { if } P 1 \geq 1 \\
=P 1 \text { If } P<1\end{array}\right. \\
P 1=l 1 / N 1\end{array} \\
\begin{array}{l}l 1=\text { Extend of sidewalk } \text { in one side }(\mathrm{m}) \\
N 1=\text { Extend of street }- \text { Extend of crossroads in one side }(\mathrm{m})\end{array} \\
m\left\{\begin{array}{l}=1 \text { if } P 2 \geq 1 \\
=P 2 \text { If } P 2<1\end{array}\right. \\
P 2=12 / \mathrm{N} 2 \\
\begin{array}{l}l 2=\text { Extend of footpath in opposite side }(\mathrm{m}) \\
N 2=\text { Extend of street }- \text { Extend of crossroads in other side }(\mathrm{m}) \\
S=(a+m) / 2\end{array}\end{array}$ \\
\hline Width of footpath & 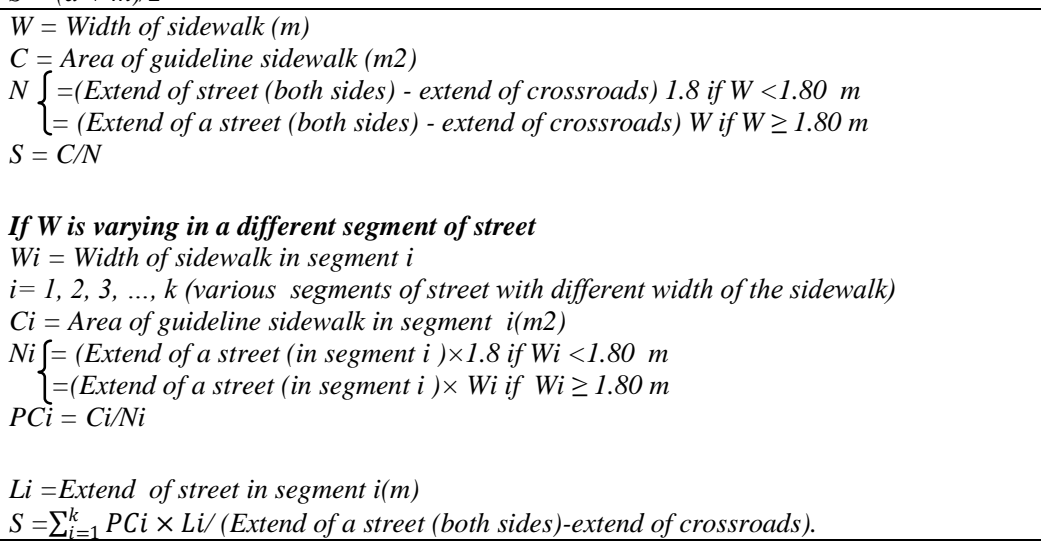 \\
\hline Slope & 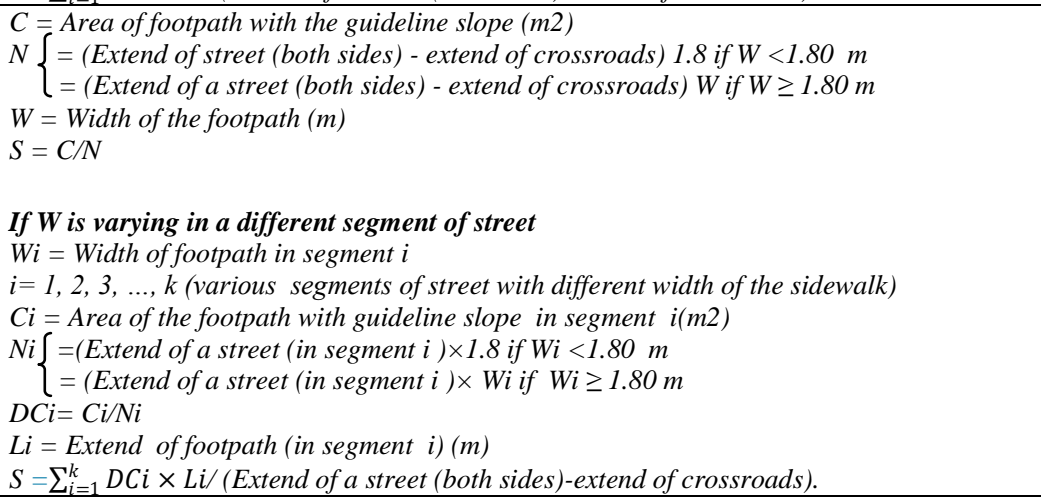 \\
\hline Lighting & 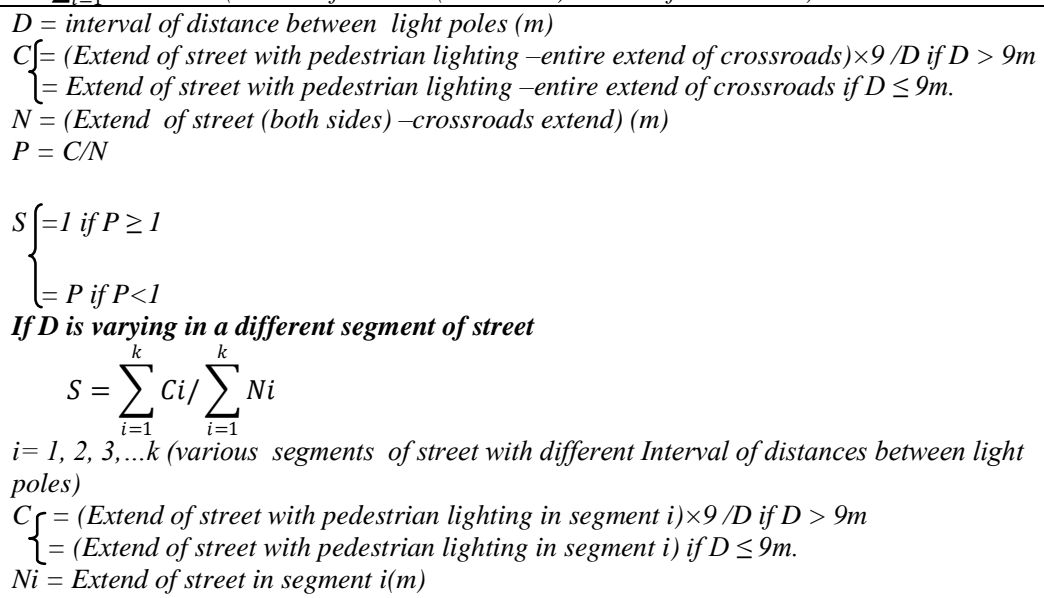 \\
\hline
\end{tabular}




\begin{tabular}{|c|c|}
\hline Continued Facilities & Scores \\
\hline Ramp & $\begin{array}{l}C=\text { Number of guideline ramps } \\
N=\text { Number of ramps that street requires } \\
P=C / N \\
S\left\{\begin{array}{l}=1 \text { if } P \geq 1 \\
=P \text { if } P<1\end{array}\right. \\
1 \text { if the street does not require ramp. }\end{array}$ \\
\hline Park and space for playing & $S\left\{\begin{array}{l}=1 \text { If there are a park and space for playing } \\
=0 \text { If there is no park and space for playing }\end{array}\right.$ \\
\hline Social space (café) & $\begin{array}{l}C=\text { Extend of a street } \text { with social spaces }+ \text { their support distance }(m) \\
N=\text { Extend of a street }(\text { in both sides) }(m) \\
S=C / N\end{array}$ \\
\hline Bench and seating area & $\begin{array}{l}C=\text { Extend of a street } \text { with guideline seating area }+ \text { their support distance }(m) \\
N=\text { Extend of a street (in both sides) }(m) \\
S=C / N\end{array}$ \\
\hline Toilet & $\begin{array}{l}C=\text { Extend of a street } \text { with guideline toilets }+ \text { their support distance }(m) \\
N=\text { Extend of } \text { a street }(m) \\
S=C / N\end{array}$ \\
\hline Pedestrian signal & 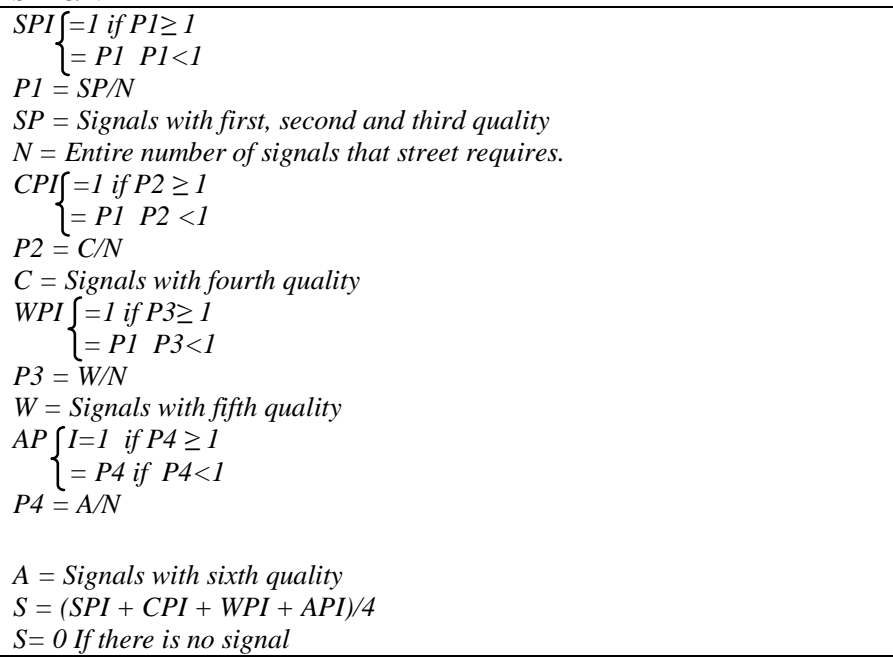 \\
\hline $\begin{array}{l}\text { Shorter crossing distance(curb } \\
\text { extension) }\end{array}$ & $\begin{array}{l}P=C / N \\
C=\text { Number of guidelines curb extensions } \\
N=\text { Entire number of curb extensions that street requires } \\
S\left\{\begin{array}{l}\text { if } P \geq 1 \\
=P \text { if } P<1 \\
=0 \text { if there is no point in requiring curb extension and there is no footpath. }\end{array}\right.\end{array}$ \\
\hline
\end{tabular}

991 
We can improve the pedestrians' comfort condition by analyzing the existing variable's qualities with standards (See Table 7 and Appendices A, B). The comfort indicators could achieve the ideal score of 1 by performing current scores.

\section{Example 1 Developing pedestrian facilities scores at street 1}

1003

1004

1005

1.1 Landscape and trees (current score $S=0$, improved score $S 1=0.62$ with trees interval distance of $15 \mathrm{~m}, \mathrm{~S} 2=1$ with trees interval distance of $9 \mathrm{~m}$ ).

\section{Where:}

$\mathrm{C}$

$\{($ Extend of a street with trees-entire extend of crossroads and their considered standard restrictions $) \times 9 / D$ If $D>9$

(Extend of a street with trees-entire extend of crossroads and their considered standard restrictions) /D If $D \leq 9$

$N=$ Extend of the street (both sides)-entire extend of crossroads and their considered standard restrictions)

$F=C-$ Extend of a street that does not have a clear vertical height

$N I=$ Number of crossroads with considered standard restrictions for trees).

$I=$ Number of the hole crossroads.

$P l=C / N$

$P 2=F / N$

$P 3=N I / I$

$S=(P 1+P 2+P 3) / 3$

\section{1. $D=15$}

$C=((515 \times 2)-72) \times 9 / 15=574.8, N=(515 \times 2)-72=958, P 1=574.8 / 958=0.60, F=958-0=958$, $P 2=974.8 / 958=0.60, N I=8, I=12, P 3=8 / 12=0.66 ;$ so,$\left.S_{l}=(0.60+0.60+0.66) / 3=0.62\right)$

2. $D=9$

We can have the ideal score of $1\left(S_{2}=1\right)$ of landscape and trees by considering the interval distance between trees $9 \mathrm{~m}$ instead of $15 \mathrm{~m}$, besides eliminating the standard length at two intersections.

\subsection{Benches and seating area}

$C=$ Extend of a street with guideline seating area + their support distance $(m)$

$N=$ Extend of a street $($ in both sides) $(m)$ 
1. The minimal required distance between benches $(D=200 \mathrm{~m})$

1020

$$
(C=500+200=700, N=(515 \times 2)=1030, S=700 / 1030=0.67
$$

1021

2. It is also possible to achieve the ideal score of 1 by considering the benches' furniture 1022 along 330m (Which included 200-400 m).

By improving only these two factors scores and maintaining PET scores, the SWTCI comfort level.

Example 2 Developing pedestrian facilities scores at Street 3 scores such as landscaping and trees, footpath pavement can enhance the scores and improve the walking experience.

2.1 Width of the footpath (current score $\mathrm{S}=0$, improved score $\mathrm{S} 1^{\prime} 0.83=$ with $\mathrm{W}=1.5 \mathrm{~m}, \mathrm{~S} 2$ '= 1 with $\mathrm{W}=2.4 \mathrm{~m}$ or $1.80 \mathrm{~m})$.

Where:

$W=$ Width of sidewalk $(m)$

$C=$ Area of guideline sidewalk $(\mathrm{m} 2)$

1035

1036

$\left\{\begin{array}{l}=(\text { Extend of street }(\text { both sides })-\text { extend of crossroads) } 1.8 \text { if } W<1.80 \mathrm{~m} \\ =(\text { Extend } \text { of } \text { a street }(\text { both sides })-\text { extend of crossroads }) W \text { if } W \geq 1.80 \mathrm{~m}\end{array}\right.$

1037

$S=C / N$

1038

1. $\mathrm{W}=\mathbf{1 . 5 0}$

1039

$$
\mathrm{C}=(299.68-5) \times 1.50, \mathrm{~N}=(299.68-5) \times 1.80, \mathrm{~S}=\mathrm{C} / \mathrm{N}, \mathrm{S} 2^{\prime}=442.02 / 530.42=0.83
$$




$$
\mathrm{C}=(299.68-5) \times 2.40, \mathrm{~N}=(299.68-5) \times 2.40, \mathrm{~S}=\mathrm{C} / \mathrm{N}, \mathrm{S} 2{ }^{\prime}=707.23 / 707.23=1 .
$$

1043 Combining footpath pavement and width of the footpath could be an excellent choice

1044 for enhancing the pedestrian comfort facilities scores. In this case, it is easy to enhance the 1045 footpath pavement because it is not existing. So it is possible to reach the score (1) directly. Where

$W=$ Width of footpath $(m)$

$C=$ Area of standard pavement $(\mathrm{m} 2)$

1049

1050

$N\left\{\begin{array}{l}=(\text { Extend } \text { of street }(\text { both sides })-\text { extend of crossroads) } 1.8 \text { if } W<1.80 \mathrm{~m} \\ =(\text { Extend of a street }(\text { both sides })-\text { extend of crossroads }) W \text { if } W \geq 1.80 \mathrm{~m}\end{array}\right.$

1051

$S=C / N$

1052

1053

$$
\mathrm{C}=(299.68-5) \times 2.40, \mathrm{~N}=(299.68-5) \times 2.40, \mathrm{~S}=\mathrm{C} / \mathrm{N}, \mathrm{S} 2{ }^{\prime}=707.23 / 707.23=1 .
$$

1054 However, proposing a specific type of footpath pavement material such as tiles with a 1055 lighter is an interesting alternative to enhance thermal comfort. $\mathrm{D}=9 \mathrm{~m})$.

\section{Where:}

$D=$ interval of distance between light poles $(m)$

1060

1061

$C\left\{\begin{array}{l}=(\text { Extend of street with pedestrian lighting -entire extend of crossroads }) \times 9 / D \text { if } D>9 m \\ =(\text { Extend of street with pedestrian lighting -entire extend of crossroads }) \text { if } D \leq 9 m .\end{array}\right.$

$N=($ Extend of street $($ both sides $)-$ crossroads extend $)(m)$

1063

$P=C / N$

1064

1065

$\left\{\begin{array}{l}=1 \text { if } P \geq 1 \\ =P \text { if } P<1\end{array}\right.$

1066

1. $D=14 m$ 
1069 $C=(299.68-5 \times 9) / 9, N=(299.68-5), P=C / N, P=1$

1070

1071

1072

1073

1074

1075

1076

1077

1078

1079

1080

1081

1082

1083

1084

1085 


\section{PART B General Importance}

Please rank the importance of the following walking indicators by selecting one number from 1 to 5 (1 not very important, 5 very important)

\begin{tabular}{|l|l|l|l|l|l|}
\hline \multicolumn{1}{|c|}{ Indictors } & $\mathbf{1}$ & $\mathbf{2}$ & $\mathbf{3}$ & $\mathbf{4}$ & $\mathbf{5}$ \\
\hline Slower traffic speed & & & & & \\
\hline Buffer and barriers (curb and furnishing zone) & & & & & \\
\hline Fewer raffic lane & & & & & \\
\hline Shorter crossing distance(curb extension) & & & & & \\
\hline Mid-block crossing & & & & & \\
\hline Social space (café) & & & & & \\
\hline Landscape and trees & & & & & \\
\hline Furniture and facilities (trash receptacle) & & & & & \\
\hline Footpath pavement & & & & & \\
\hline Marking (crosswalk) & & & & & \\
\hline Sidewalk on bothsides & & & & & \\
\hline Width of footpath & & & & & \\
\hline Standard driveway & & & & & \\
\hline Lighting & & & & & \\
\hline Slope & & & & & \\
\hline Ramp & & & & & \\
\hline toilet & & & & & \\
\hline grad & & & & & \\
\hline Pedestrian signal & & & & & \\
\hline Bench and seating area & & & & & \\
\hline Park and space for playing & & & & & \\
\hline Shade/ Thermal comfort & & & & \\
\hline
\end{tabular}

1090

1091 